\title{
EL ISLAM POPULAR A TRAVÉS DE LA ÓPTICA COLONIAL: LA TARĪQA DARQĀWIYYA Y EL PROTECTORADO DE ESPAÑA EN MARRUECOS
}

\section{POPULAR ISLAM THROUGH A COLONIAL PERSPECTIVE: THE ȚARĪQA DARQĀWIYYA AND THE SPANISH PROTECTORATE OF MOROCCO}

Jorge Villanueva Farpón

\section{Resumen}

La empresa colonial europea en el norte de África y Oriente Medio estuvo respaldada desde sus principios por un aparato científico y académico que completaba la acción militar. Como en otros territorios bajo dominio europeo, Marruecos se convirtió en objeto de estudio para su colonización y control: su geografía, sus poblaciones, su historia, sus prácticas religiosas y culturales y, por supuesto, sus organizaciones e instituciones. En este aspecto, las cofradías religiosas (en árabe țarīqa, pl. $\operatorname{tur} \bar{u} q)$ eran organizaciones con un gran poder e influencia social y religiosa, y estaban extendidas por todo el territorio. En la parte norte de Marruecos, la zona que se correspondería con el Protectorado de España en Marruecos, la țarīqa más influyente era la Darqāwiyya, extendida también por el resto del país y por todo el norte de África y enclaves de Oriente Medio. Esta institución, que ya había sido estudiada por el temprano colonialismo francés, se mantendría en el punto de mira de los servicios de información españoles durante todo el período colonial, ya que era considerada, por sus redes clientelares y prestigio social y religioso, como un agente peligroso y dañino para el éxito de la empresa colonial. Debido a su alto grado de fragmentación, no podremos hablar de un liderazgo ni de una política de acción únicos de esta cofradía, pues cada líder de las distintas ramas actuaría respondiendo a una política y a unos intereses propios en sus relaciones con los poderes marroquíes y coloniales. Este artículo examina los orígenes de los Darqāwa y sus distintas ramas establecidas en el norte de Marruecos, así como el origen de la imagen negativa de esta cofradía en las primeras fuentes coloniales; una imagen que fue perpetuada y confirmada por los agentes coloniales españoles. A través de varios episodios significativos, analizaremos la postura de los líderes de la țarīqa ante las rebeliones al poder colonial de Aḥmad al-Raysūnī y 'Abd al-Krim al-Khaț̣ābī, las relaciones y juegos de poder entre estos líderes y los agentes coloniales durante 
la guerra civil española y sus posturas ante el nacimiento y auge del nacionalismo marroquí en la zona norte. A través de estas distintas etapas podremos concluir que, a pesar de la imagen negativa y la desconfianza de la que gozaban los Darqāwa, lo cierto es que existió la colaboración entre ambas partes en numerosas ocasiones para beneficio mutuo.

Palabras clave: Marruecos; Colonialismo; Protectorado Español; Tarīqa; Darqāwa.

\begin{abstract}
Since its origins, the European colonial venture in North Africa and the Middle East was supported by a scientific and academic system that complemented military action. Like other territories under European control, Morocco became an object of study for the purposes of colonization and monitoring of its geography, its populations, its history, and its religious and cultural practices and, of course, its organizations and institutions. Among the organizations that elicited colonial interest were religious brotherhoods (in Arabic țariqa, pl. țurūq), which had great religious and social power and influence throughout the country. In Northern Morocco, the area that would eventually become the Spanish Protectorate in Morocco, the most powerful tariqqa was the Darqāwiyya, whose presence also extended to the rest of the country, North Africa and some areas of the Middle East. This institution, which had already been studied by the early French colonial authorities, was a target of the Spanish information services all along the colonial period. The Darqāwiyya was seen as a threat to the success of the colonial venture due to its clientele networks and its social and religious prestige.

Given that this brotherhood was a fragmented institution, it is impossible to single out a sole leader or a unique politics of action that characterized the entire Darqāwiyya. Instead, the leaders of the different branches of the Darqāwiyya acted according to their particular interests in their relationships with Moroccan and colonial powers. This paper examines the origins of the Darqāwa and its different branches established in Northern Morocco, as well as the origin of the negative portrayals of this brotherhood in the first colonial sources; portrayals that were perpetuated and affirmed by Spanish colonial agents. Through an in-depth examination of several key events, we will analyse the position of the Darqāwa leaders towards the rebellions of Ahmad al-Raysūnī and 'Abd al-Krim al-Khațāāi against colonial authorities. In addition, we will discuss the relationships and power games between these leaders and colonial agents during the Spanish Civil War, and their positions towards the rise and flourishing of Moroccan nationalism in the North of the country. Across these different historical moments, we will conclude that, despite the negative view and the mistrust in which the Darqāwa were depicted in colonial sources, both parties collaborated with each other on several occasions for their mutual benefit.
\end{abstract}

Keywords: Morocco; Colonialism; Spanish Protectorate; Tariqa; Darqawa. 


\section{Introducción}

El aspecto militar de la empresa colonial europea en el norte de África estuvo acompañado, casi desde un principio, por todo un abanico de estudiosos. El ejército colonial francés, el primero en comenzar la conquista de los territorios norteafricanos, contaba con un equipo de académicos y especialistas de distintas disciplinas que desarrollarían su labor al servicio de la empresa colonial. Mientras que la ocupación francesa de Argelia, que había comenzado en 1830, avanzaba militarmente por todo el territorio de la entonces provincia otomana, se desarrollaban también multitud de obras y trabajos sobre diversos aspectos de los pueblos y de la orografía que se pretendía dominar. Desde estos inicios y a lo largo de todo el período colonial, aparecerían obras como monografías, tratados, artículos, relatos de viajes y demás que abarcarían las disciplinas más variadas: biología, medicina, geografía, historia, antropología... Pero quizá los temas más desarrollados fueron aquellos que trataban sobre grupos e instituciones sociales, económicas y religiosas que afectaban de manera directa al ejercicio del poder colonial, es decir, a las relaciones entre colonizador y colonizado.

Es este aspecto el que nos ocupa, ejemplificado en la producción académica colonial francesa sobre una de las cofradías religiosas musulmanas (en árabe tarīqa) más importantes de todo el norte de África durante el siglo XIX y la primera mitad del siglo XX. Una tarīqa es una organización religiosa musulmana que aparece en torno a la figura, por regla general, de un santo. Puesto que en el Islam no existe una jerarquía religiosa institucionalizada, el proceso de santificación (es decir, el proceso por el cual un hombre de religión pasa a ser considerado santo) proviene del consenso popular. Las cofradías han estado muy ligadas a la historia política y religiosa de Marruecos, y su influencia ha sido clave a la hora de entronizar o deponer a los soberanos. En el período de la historia que nos concierne, las cofradías ya estaban plenamente instauradas y presentaban las características que las conocieron los agentes coloniales.

Tras una breve introducción histórica sobre el nacimiento y desarrollo de esta cofradía, la țarīqa Darqāwiyya, trataremos los primeros contactos con el colonialismo francés y el origen de la imagen negativa que después se perpetuaría en el colonialismo español en Marruecos. Nos detendremos en el establecimiento de sus distintas ramificaciones en el norte de Marruecos, la zona que correspondería al Protectorado español. Este gobierno colonial, desde su establecimiento en 1912, estuvo dominado por el estamento militar, debido entre otras causas, a la existencia 
de rebeliones y levantamientos contra el poder colonial, que provocaría la preponderancia de las acciones $\mathrm{mi}$ litares sobre el resto de aspectos de la colonización. Durante estas rebeliones, los líderes de la cofradía no permanecerían al margen, y desarrollarían sus propias estrategias conforme a sus intereses y a la situación. Tras el final de las hostilidades, en 1927, los servicios de información españoles aumentarían la vigilancia de estos líderes y personajes influyentes pertenecientes a la Darqāwiyya, que eran vistos como un enemigo contrario a la empresa colonial española. No obstante, no podremos hablar de una única política o de una relación maniquea, puesto que entre las autoridades coloniales y los Darqāwa se estableció todo un abanico de relaciones que iban desde la colaboración hasta la desconfianza absoluta e incluso el encarcelamiento de alguno de sus cofrades. A través de varios episodios históricos significativos, podremos demostrar que, pese a que las fuentes coloniales reproducen una imagen muy negativa de la cofradía, que tiene su origen en la producción académica colonial francesa que mencionábamos al principio, lo cierto es que esta visión no impedía la colaboración de colonizadores y colonizados.

\subsection{El origen de la cofradía}

El fundador de la țarīqa, Abū 'Abd Allāh Muḥammad al- 'Arabī al-Darqāwī (m. 1823), procedía de la cabila de Banī Zarwāl, situada en la montaña rifeña, al norte de Fez. Las primeras fuentes coloniales francesas nos dicen que esta cabila controlaba un terreno fértil con una actividad agrícola extensa y como paso de una importante ruta comercial de montaña ${ }^{1}$. Esta característica será decisiva para el crecimiento de la cofradía, puesto que ejercer algún tipo de control (religioso en este caso) sobre una región tan fértil e importante para la economía rifeña supondría detentar un poder considerable en el norte de Marruecos, en una zona geográfica que escapaba tradicionalmente al control efectivo del sultán marroquí. Estudiando en Fez conoció a su maestro más influyente, Mūlāy 'Alī bin 'Abd al-Raḥmān al-'Imrānī alFāsī, más conocido como al-Ŷamal (el Camello), de quien se sentiría heredero a su muerte ${ }^{2}$. Alrededor de 1788 al-Darqāwī fundaría su primera zāwiya en su cabila de origen, en el poblado de Bū Barī $h^{3}$. Entendemos por zāwiya un centro cultural y religioso de una cofradía,

1 Édouard Michaux-Bellaire, "Les Derqaoua de Tanger", Revue du Monde Musulman XXXIX" (1920): 98-118.

2 Najiba Agherrabi, Le Soufi marocain My al-Arbi al-Darqâwî (Rabat: Dar Lamane, 2010), 38.

3 Esta aldea aparece ya en la historiografía colonial en Auguste Mouliéras, Le Maroc inconnu: étude géographique et sociologique, Deuxième Partie: Exploration des Djebala (Maroc Septentrional) (París: Challamel, 1899), 88, como Bu Barih, y la transcripción se repite en fuentes posteriores. No obstante, en la obra de Mustapha Al-Rayis, I $d \bar{a}^{\prime} \bar{a} t$ hawla al-zawāya wa-l-turuqiyya zamān al-himāya (Salé: Mațba'at Banī Yazānsin, Manshūrāt alZamān, 2016), la aldea aparece como Bu Bariy. 
donde se congregan los adeptos, y que, según su importancia y localización, puede desarrollar otras funciones como alojamiento, escuela religiosa, foco comercial o como centro político.

El círculo de discípulos de al-Darqāwī creció rápidamente, abarcando todas las clases sociales. Muchos notables se adhirieron a la doctrina que predicaba, y las masas populares, tanto en las ciudades como en el campo, se afiliaron a la nueva tarīqa. La situación geográfica de la tribu donde se encuentra (todavía hoy) la zāwiya madre y el gran número de discípulos afiliados permitieron que la cofradía conociera un gran crecimiento y expansión en poco tiempo ${ }^{4}$. Se extendió rápidamente por el Oranesado 5 (territorio argelino, aunque con unas fronteras con Marruecos muy difusas históricamente). Los discípulos que se congregaban para recibir las enseñanzas en Bū Barīh volverían a sus lugares de origen y fundarían zawāya (pl. de zāwiya) filiales de la sede central. La importancia y la calidad de los adeptos a la cofradía, así como la importante red que tejían por todo el territorio,

4 Sobre la aparición de la tarīqa y su evolución histórica véase Abdallah, Stititu, "Al-zawiya wa-l-muytama' al-qabili wa-1-majzan (al-zawiya al-Darqāwiyya namudya)", Minbar Muhammad 'Abid al-Yabri, http://www.aljabriabed.net/ n94_06stitou.htm (consultado el 18 de septiembre de 2016).

5 George Drague, Esquisse d'histoire religieuse au Maroc. Confréries et Zaouias (París: Peyronnet, 1951), 102. llevarían a la Darqāwiyya a ocupar un papel primordial en la sociedad de su tiempo, llamando la atención de las autoridades marroquíes y, por supuesto, de los colonizadores.

A su muerte, los distintos discípulos que había congregado fundaron sus propias zawāya y la cofradía se ramificó, siendo imposible hablar desde entonces de un único liderazgo de la tarìqa, y mucho menos de una política de actuación conjunta. Cada líder respondería a sus propios intereses y necesidades. Sin embargo, podemos decir que la zāwiya madre situada en Banī Zarwāl siguió ejerciendo una suerte de liderazgo moral, por haber sido el lugar de fundación de la Darqāwiyya, y muchos adeptos siguieron enviando sus ofrendas y yendo en peregrinaje al hogar de al-Darqāwī. Sus descendientes continuaron ejerciendo el liderazgo en esa cabila, siendo además la Darqāwiyya la cofradía más importante del Rif en el período que nos ocupa.

\subsection{Los Darqāwa y el primer contacto con el colonialismo francés}

La segunda mitad del siglo XIX en el norte de África está marcada por la ocupación francesa de Argelia, su progresiva penetración en territorio marroquí y el establecimiento del Protectorado francés de Túnez. En julio de 1830, los franceses desembarcaron cerca de Argel; el acontecimiento causó pánico en Marruecos, ya que las fronteras 
entre ambos países siempre habían sido permeables. Además, cofradías como la Darqāaiviyya mantenían importantes emplazamientos en el oeste de Argelia que suponían una fuente importante de recursos. El entonces sultán marroquí 'Abd al-Raḥmān (r. 1822-1859) aceptó embarcaciones de refugiados procedentes de Orán ${ }^{6}$, y más adelante se decidió a intervenir del lado del emir argelino 'Abd al-Qādir, que se había rebelado contra la ocupación francesa, y se vio envuelto en el conflicto. En la batalla de Isly en agosto de 1844 las fuerzas francesas derrotaron al ejército del sultán, que se vio obligado a firmar el tratado de Tánger, comprometiéndose a capturar al emir argelino, y el convenio de Lalla Maghniyya, por el que aceptaba una demarcación fronteriza con los franceses, reconociendo de facto su presencia en Argelia?' 'Abd al-Qādir intentaría atraer a su causa a los Darqāwa argelinos, por entonces muy numerosos e importantes, pero sin éxito. Se enfrentó a un grupo de adeptos encabezados por un muqaddam darqāwī (delegado de la cofradía con distintas funciones según su importancia), a los que venció en abril de $1835^{8}$, y estudios coloniales y posco-

6 Susan Gilson Miller, Historia del Marruecos moderno (Madrid: Akal, 2015), 28.

7 Susan Gilson Miller y Amal Rassam, "The View from the Court: Moroccan Reactions to European Penetration during the Late Nineteenth Century", The International Journal of African Historical Studies, 16-1 (1983): 25-38.

8 Pessah Shinar, "'abd al-Qadir and 'abd al-Krim Religious Influences on Their Thought and Action”, en Modern Islam in the Maghrib, Pessah loniales hacen referencia a varios enfrentamientos del emir con otros líderes de la tarīqa en Argelia, que le acusaban de haber pactado con los franceses a raíz de los acuerdos de Demischels (1834) y Tafna (1837) 9 .

Nos parece importante hablar de la situación política puesto que algunas ramas de la tarīqa tomarán parte en la lucha activa contra la penetración francesa, primero en Argelia y después en Marruecos, cuando Francia cruce las fronteras y vaya asentándose en el país. En el marco colonial de producción científica diversa, se explotaría la dicotomía de bilād al-makhzan (país del Estado) y bilād al-sìba, entendiendo este último como un sinónimo de «anarquía», de todo aquello que escapa al control efectivo del sultán, para probar que la soberanía del sultán en las regiones periféricas de Marruecos era una ficción y legitimar así la extensión de la llamada paix française en estas regiones $^{10}$. Sabemos, sin embargo, que tal dicotomía no era maniquea y que las cabilas en disidencia siempre mantuvieron una variedad de relaciones con

Shinar (Jerusalén: Hebrew University of Jerusalem, 2004), 139-174.

9 André Cochut, "Les Khouan. Moeurs religieuses de l'Algérie", Nouvelle Revue de Bruxelles, 2 (1846): 589-611; Ahmed Nadir, "Les ordres religieux et la conquête française (1830-1851)", Revue algeriénne des sciences juridiques, politiques et économiques, 9:4 (1972): 819-872.

10 Pascal Venier, "French Imperialism and pre-colonial rebellions in Eastern Morocco, 1903. 1910", The Journal of North African Studies, 2:2 (1997): 57-67. 
el Majzén. Es esta voluntad colonialista la que debemos tener en cuenta a la hora de tratar con algunos datos e informaciones que nos proporcionan las obras producidas durante este período, puesto que tienen como finalidad conocer el territorio y las poblaciones que se quieren someter, y no se tratará de trabajos objetivos, sino cargados de una clara intención de dominación.

Por la rápida extensión y ramificación de la cofradía, esta contaba con zawāya por todo el territorio, como así se manifiesta en un informe colonial español sobre la historia de esta cofradía:

«En Marruecos, no hay tribu que no cuente con un cierto número de huidos darkauas; se citan zawiyas importantes en Fez, Marrakech, Medjour, Kerker (Rif); otras secundarias en casi todas las ciudades, tribus del imperio y corporaciones cherifianas, sobre todo en los alrededores de $\mathrm{Fez}(\ldots)$ que continúan los rituales de los darkauas. Se puede considerar como la cofradía más importante de Marruecos (...) Muy numerosos en Touat y en Gomara, los darkauas están además esparcidos por todo el Sáhara hasta Tombuctou, donde sus zawiyas de Touzinin y Madaghra están representadas por los moqaddemin $\mathrm{Si}$ Mohammed y Alid, este último comerciante de los Tadjakaut ${ }^{11}{ }$.

11 Regional de Gomara, Delegación de Asuntos Indígenas (DAI), Servicio de Información, Publicaciones, Algunos datos sobre darkanas y aliuas, s.a.: 7 .
De todas las ramificaciones en territorio marroquí, la que más aparece en las fuentes coloniales francesas y a la que se le ha dado un mayor protagonismo durante la penetración colonial ha sido la zāwiya de los shurafa $\bar{a}$ (jerifes, descendientes del Profeta) de Madaghra, en el sureste de Marruecos. Aunque varios autores coloniales recogen sus impresiones sobre el sharif de Madaghra y sus intenciones de luchar contra el avance francés, como fórmula para justificar el aumento de la presencia e intervención francesas en la zona, Lacroix reconoce que tal amenaza solo se les ha presentado en forma de rumor y cargada de cierta leyenda ${ }^{12}$. Las fuentes coloniales recogen rumores de revuelta en 1885 y 1887 , que parece que no suponen un desafío mayor para las tropas francesas que otras rebeliones y sublevaciones vencidas anteriormente ${ }^{13}$. En $1892 \mathrm{el}$ sharif de Madaghra moría a los noventa y dos años, y como ha ocurrido en numerosas ocasiones a la muerte de un shaykh carismático, sus sucesores no se ponen de acuerdo y la causa y el prestigio que habría podido tener la zāwiya van disminuyendo a medida que se suceden las disputas. El nuevo líder no adoptaría el discurso de su predecesor, y ante el continuo avance y ocupación

12 Napoleón Lacroix, Les Derkaoua d'hier et d'aujourd'hui (Argel: Victor Heintz, 1902): 18.

13 Gilson Miller y Rassam, "The View from the Court: Moroccan Reactions to European Penetration during the Late Nineteenth Century", 20. 
de las tropas coloniales francesas, los líderes acabarían haciendo acto de sumisión y adaptándose a la nueva situación de poder.

\subsection{La imagen negativa de los Darqāwa}

Fruto de estas rebeliones, de algunas tentativas y de las acaecidas en épocas anteriores en territorio argelino, primero contra el poder turco y más tarde en respuesta a la ocupación francesa, el colonialismo forjó una visión negativa de la tarīqa y de sus adeptos. $\mathrm{Si}$ bien es cierto que algunos líderes que encabezaron revueltas muy localizadas, y ciertas con mayor repercusión, pertenecían a la cofradía, la mayoría de los adeptos que se afiliaban a la Darqāwiyya no tomaron parte en estos levantamientos. Existieron durante la ocupación francesa de Argelia multitud de rebeliones y respuestas violentas a la penetración extranjera, pero la mayoría no las instigaron líderes carismáticos de la cofradía. En Argelia, al igual que en Marruecos, estaban presentes la mayoría de cofradías existentes en la época, además de numerosas familias de shurafa $\bar{a}$ ' que no se adherían a una tarīqa en concreto. Estos personajes también fueron protagonistas de los alzamientos en contra de la invasión colonial y tomaron parte en la oposición violenta contra las tropas francesas.

La visión negativa de los Darqāwa no constituye una excepción a la visión del colonialismo francés de algunas cofradías que se opusieron, al menos en un primer momento, a su penetración en el norte de África. En esta línea, los etnógrafos coloniales del siglo XIX y principios del XX vieron estas țurūq (pl. de țarīqa) como posibles núcleos de conspiraciones «panislámicas» potencialmente manipulables por el Imperio Otomano y por los poderes coloniales rivales, que podrían debilitar su dominio y objetivos en el norte de África ${ }^{14}$. Consciente de la importancia política y social de estas organizaciones, el colonialismo intentaría atraer a su causa a sus líderes y establecer con ellos relaciones de clientela y de beneficio mutuo. Si esto no era posible, otras estrategias a seguir eran el acoso y la persecución de sus miembros, la difusión de falsos rumores o la promoción de otras țurūq, afines a sus voluntades, en aquellas zonas en las que la cofradía que se buscaba eliminar tuviera una presencia mayoritaria ${ }^{15}$. Si nos centramos en la Darqāwiyya, la imagen de un colonialismo temprano en Argelia se afianzará y se extenderá a la hora de hablar de los Darqāwa marroquíes ${ }^{16}$. El capitán francés De Neveu fue uno de los primeros autores en difundir esta imagen negativa

14 Dale F. Eickelman, Antropología del mundo islámico (Barcelona: Bellaterra, 2003): 387.

15 Abdallah Stititu, http://www.aljabriabed.net/ n94_06stitou.htm (consultado el 18 de septiembre de 2016).

16 François Édouard De Neveu, Les Khouan. Ordres religieux chez les musulmans de l'Algérie (Argel: Adolphe Jourdan, 1846): 172-173. 
y de amenaza para la empresa colonial, y la mayoría de autores franceses remarcaban el carácter político de la cofradía $^{17}$. Depont y Coppolani consideraban la tarīqa como contraria a la expansión francesa ${ }^{18}$, y La Martinière sostenía que los Darqāwa escondían importantes depósitos de armas ${ }^{19}$. Una de las causas de esta visión negativa era la obediencia que los discípulos de la cofradía le debían a su shaykh, que recogen multitud de autores cuando tratan la tarīqa, si bien este precepto de obediencia no era exclusivo de la Darqāwiyya, y es una constante en las relaciones de poder vertical en la sociedad marroquí20. Otro aspecto que preocupaba a los colonialistas era, como refleja el título de este trabajo, el rechazo a detentar el poder temporal y a aquellos que lo ejercen:

«Los darqāwa constituyen en el Noroeste de África una cofradía que profesa verdaderas doctrinas anarquistas. Predican el odio al poder absoluto y unen en una misma palabra las enseñanzas de abstención

17 Josep Lluís Mateo Dieste, La «hermandad» hispano-marroquí. Política y religión bajo el Protectorado español en Marruecos [1912-1956] (Barcelona: Bellaterra, 2003): 340.

18 Octave Depont y Xavier Coppolani, Les confréries religieuses musulmanes (Argel: Adolphe Jourdan, 1897).

19 Édouard Montet, "Les confréries religieuses de l'islam marocain: leur rôle religieux, politique et social", Revue de l'histoire des religions, 45 (1902): 1-35.

20 Abdallah Hammoudi, Maestro y discípulo. Fundamentos culturales del autoritarismo en las sociedades árabes (Barcelona: Anthropos, 2007). completa y de hostilidad hacia los detentores del poder temporal ${ }^{21}$ ».

Michaux-Bellaire hablaba de «pandarcauismo» a la hora de referirse al peligro de la cofradía, que consideraba contraria a todo poder extranjero $^{22}$. Esta visión colonial negativa se reproduciría en el ambiente colonialista español, cuando la obra de Michaux-Bellaire fue traducida por el intérprete Clemente Cerdeira en 1923, en plena guerra del Rif. Sin embargo, no todos los autores asumieron esta imagen negativa. Rinn reconoce que, si bien rehúsan emplearse en la administración colonial, no tienen una actitud agresiva ni hostil hacia el colonialista ${ }^{23}$. En esta misma línea, el francés Montet desmiente las acusaciones de fanatismo de la cofradía ${ }^{24}$, y Lacroix, en su monográfico sobre la tarīqa, hace hincapié en la necesidad de distinguir las ambiciones personales de alguno de sus líderes con el conjunto de la cofradía ${ }^{25}$.

21 Jacob Schaudt, "Voyages au Maroc", Bulletin de la Société de Géographie d'Alger et de l'Afrique du Nord, VI-III (1901): 235.

22 Édouard Michaux-Bellaire, Apuntes para la historia de las cofradías musulmanas marroquíes (trad. Clemente Cerdeira) (Madrid: Editorial Ibero-Africana-Americana, 1923): 40.

23 Louis Rinn, Marabouts et khouan. Étude sur l'islam en Algérie (Argel: Adolphe Jourdan, 1884): 262.

24 Édouard Montet, "Les confréries religieuses de l'islam marocain: leur rôle religieux, politique et social", 18.

25 Napoleón Lacroix, Les Derkaoua d'hier et d'aujourd'hui, 33. 
El cambio de postura llegaría más tarde, durante la guerra del Rif, cuando el shaykh de la zāwiya madre, 'Abd al-Raḥmān al-Darqāwī, por entonces principal agente de la política francesa en la cabila, se opusiera al proyecto político de 'Abd al-Krim ('Abd al-Karīm al-Khațāōi) e intentara detener su influencia en la rebelión que estaba preparando. Su apoyo a Francia le valió la quema de su zāwiya en 'Amyūtṭ durante la guerra, cuando tuvo que refugiarse en Fez hasta el final de la contienda. A finales de los años cuarenta y principios de los cincuenta del siglo XX, Drague recogería en sus trabajos numerosos ejemplos de colaboración de distintos líderes de turūq y zawāya marroquíes y postularía por una revisión de la imagen negativa que el primer colonialismo había construido respecto a muchos de el$\operatorname{los}^{26}$. Esta revisión se debía, al menos en parte, a la creciente importancia del nacionalismo marroquí desde los años treinta, que veían a los líderes de las cofradías como colaboracionistas con las autoridades coloniales y contrarios a su causa. Las turūq se habían convertido, paulatinamente desde el establecimiento del Protectorado, en clientes y colaboradores de los nuevos poderes que gobernaban Marruecos, y estos mismos poderes intentarían utilizar a las cofradías como contrapeso a

26 Drague, Esquisse d'histoire religieuse au Maroc. Confréries et Zaouias, 270. la influencia y creciente popularidad del nacionalismo.

\section{La tarīqa en el Protectorado español de Marruecos}

La zāwiya (lit. "esquina, rincón”) se presenta como el motor de la vida comunal de una tarīqa. Dependiendo del lugar donde sean construidas y las funciones que cumpla en su entorno, el edificio adquirirá una u otra tipología que responderá a las necesidades que cubra la zāwiya y sus fundadores y adeptos. Así, una zāwiya construida en una ciudad (como la Harrāqiyya en Tetuán o la Fāsiyya en Fez) se adaptará a las funciones que cumpla (lugar de reunión de los fieles, centro educativo del barrio o de la zona, punto de encuentro de los notables afiliados...). Por otra parte, una zāwiya construida en una cabila tomará una forma distinta ya que responderá a funciones y necesidades diferentes ${ }^{27}$.

Tanto las zawāya erigidas en ciudades, como las de Tetuán y Tánger, como aquellas construidas entre las cabilas (que, en el caso de la Darqāwiyya, contaba con edificios en la mayoría de cabilas de la zona norte de Marruecos), no conformarán realidades aisladas a su entorno y a los acontecimientos y problemas políticos, económicos y

27 Rachida Chih, "Sainteté, maîtrise spirituelle et patronage: les fondements de l'autorité dans le soufisme", Archives des sciences sociales des religions, 125 (2004): 79-98. 
sociales del momento. Según a qué lealtades estuvieran sujetas, tomarán unas u otras líneas de actuación y comportamiento con el resto de turūq, con el resto zawāya de la misma cofradía y con los poderes marroquíes y coloniales. Estos últimos eran conscientes del poder social y económico, y por derivación político, con el que contaban los líderes carismáticos e importantes de la tarīqa en sus respectivas zonas de influencia. Uno de los pilares de su importancia eran los ingresos que las zawāya obtenían fruto de las aportaciones y donaciones de sus fieles, en forma de regalos (hadāya, pl. de hadīya), otras, fruto de la peregrinación a la tumba del santo o de sus descendientes (mawsim), y de los recorridos que hacían los muqaddamin y los shuyükh de la tarīqa por el territorio, recaudando en forma de dinero o especie, denominadas ziyārāt ( $\mathrm{pl}$. de ziyāra, del verbo zāra "visitar"). Estas visitas variaban en tiempo y duración, y suponían un porcentaje importante del beneficio total con el que se mantenían la zāwiya y sus integrantes ${ }^{28}$.

\subsection{La zāwiya madre de Banī Zarwāl}

A pesar de las posteriores ramificaciones, la zāwiya madre siguió ejerciendo una suerte de superioridad moral sobre el resto, y ha sido siempre considerada como el centro principal

28 Fenneke Reysoo, Pèlerinages au Maroc (París: Editions de la Maison des sciences del'homme, 1991): 60 . de la cofradía. Aunque no se reconozca la autoridad absoluta de su shaykh sobre el resto, las otras zawāya darqāwa le enviaban la șadāqa, los beneficios de la 'imāra anual, como recogían los servicios de información españoles sobre los Darqāwa ${ }^{29}$. En esta cabila sería la tarìqa predominante e incontestable, que también ejercería su influencia en las cabilas rifeñas cercanas, que contarían con zawāya dependientes.

En pleno avance francés por Argelia y cada vez con mayor presencia en Marruecos, La Martinière y Lacroix recogen en su estudio del noroeste africano (promocionado por el Service des Affaires Indigènes), que el poder religioso y político se encontraba en manos del sharîf de Bū Barī ${ }^{30}$. Cuando se establecieron los Protectorados en 1912, la cabila quedó teóricamente incluida en la zona de influencia española, pero los franceses, conscientes de su importancia para la economía del Rif y como enclave estratégico de paso entre la llanura y la montaña, situada en una ruta comercial, buscaron su administración. Así la cabila quedó en el dominio nominal francés, unidos por intereses comerciales, aunque en teoría pertenecía a la zona de influencia

29 Regional de Gomara, DAI, s.a.

30 Maximilien La Martinière, A.C.H.P. y Napoleón Lacroix, Documents pour servir a l'étude du Nord Ouest Africain, Tome 1: Régions limitrophes de la frontière algérienne; les Rif, les Djebala (Argel: Service des Affaires Indigènes, 1894): 386-387. 
española ${ }^{31}$. Tras 1912 los representantes de los Banī Zarwāl habrían entablado buenas relaciones con los franceses, y 'Abd al-Raḥmān al-Darqāwī, el shaykh de la zāwiya de 'Amyūtṭ, era, ya en 1915, el principal cliente de la política e intereses galos en la cabila ${ }^{32}$.

\subsection{La zāwiya al-Ḥarrāqiyya de Tetuán}

Tetuán, junto con Tánger, era y es una de las ciudades más importantes del norte de Marruecos. Aunque no tenía una actividad marítima tan importante como Tánger, sí que era un enclave comercial para tener en cuenta para las cabilas de alrededor, y a ella acudían los marroquíes del norte en busca de formación y oportunidades. Constituía un enclave estratégico para dominar las regiones septentrionales de Marruecos, y así lo corroboraba el hecho de que los españoles establecieran en ella la capital de su Protectorado en 1912. Los españoles ya habían entrado durante la guerra de 1859-1860, cuando los generales Prim y O'Donnell la ocuparon hasta la firma del tratado de paz. En esta misma ciudad residía Abū 'Abd Allāh Muḥammad bin Muḥammad bin 'Umar al-Ḥarrāq (m. 1845), uno de los discípulos de al-Darqāwī. La zāwiya Darqāwiyya fue fundada alrededor de 1828 y costeada

31 María Rosa de Madariaga, Abd-el-Krim El Jatabi, la lucha por la independencia (Madrid: Alianza, 2009): 251.

32 Pessah, "'Abd al-Qadir and 'Abd al-Krim Religious Influences on Their Thought and Action," 2004. por uno de los discípulos de al-Ḥarrāq, un tal Tukurt, que puso sus bienes a disposición de su maestro ${ }^{33}$.

Al-Harrāq se había iniciado en la tarīqa en 1818-1819, y era descendiente de un ministro del sultán Mūlāy Ismā'îl. Que al-Darqāwī recibiera discípulos procedentes de las clases altas de la sociedad, además del gran espectro que abarcaba su doctrina, implicaría una voluntad de hacer la țarīqa más deseable a ojos de la élite y de desmarcarse de una concepción equívoca de la Darqāwiyya como cofradía heterodoxa y de prácticas cuestionables. La Harrāqiyya contaba con tres zawāya en Tetuán, de las que la principal, la erigida en 1828 , estaba situada frente a la puerta del cementerio $(b \bar{a} b$ al-maqābir), donde aún se encuentra hoy en día. Esta zāwiya fue utilizada como hospital de sangre, inaugurado en febrero de 1860, cuando las tropas españolas ocuparon Tetuán.

Sería uno de los hijos del anterior, Sìdī 'Idrīs al-Ḥarrāq (m. 1934), quien entre en contacto con los españoles al establecimiento del Protectorado y de su capital en Tetuán. 'Idrīs dirigía una zāwiya urbana $\mathrm{y}$, teniendo en cuenta su ascendencia, quizá este centro estuviera dirigido más a la élite social e intelectual de la ciudad que otras zawāya de cofradías más populares

33 Fernando Valderrama, "Las zawiyas de Tetuán (estudio epigráfico)", Separata de Tamuda, I: II (Tetuán: Imprenta Cremades, 1953): 3. 
presentes en la ciudad. A ella pertenecían muchos de los eruditos y sabios tetuaníes de su época ${ }^{34}$, por lo que la zāwiya podría haber tomado la función de un centro de reunión, debate y promoción de la élite intelectual de la ciudad. El shaykh de la Harrāqiyya entabló relaciones de clientela desde un primer momento con los españoles. A cambio de ejercer su influencia para calmar a los ciudadanos ante el establecimiento del gobierno de una potencia extranjera no musulmana, los españoles concedían ayudas y privilegios al shaykh y su círculo. Como veremos más adelante, al-Harrāq ayudó a la penetración de los españoles en los territorios sobre los que tenía influencia, es decir, en aquellos en los que existían zawāya afines o clientes de la de Tetuán. Además, al inicio y durante la guerra civil española, fomentó la recluta de marroquíes para las filas del bando sublevado.

\subsection{La zāwiya al-Ṣiddīqiyya de Tánger}

Tánger quizá haya sido la ciudad marroquí de mayor importancia para la política internacional, al menos hasta la independencia del país en 1956. Su privilegiada posición estratégica como punto de encuentro de África y Europa, y como paso entre el mar Mediterráneo y el océano Atlántico hicieron de Tánger un enclave deseado. Con la firma de los tratados de Protectorado

34 Tuhami Al-Wazzani, Az-Zawiya (Tetuán: Maktabat an-Nasr, 1942): 153-203. de Francia y España sobre Marruecos en 1912, se delimitaban las zonas de influencia de estos países en Marruecos, así como las fronteras de la zona de Tánger y su estatuto internacional ${ }^{35}$. En el aspecto religioso, en Tánger se encontraban representadas la mayoría de las cofradías marroquíes, si bien su número de adeptos, público y popularidad variaba considerablemente. En cuanto a la tarīqa Darqāwiyya, la construcción de su zāwiya en Tánger data de 1903-1904, en un período de creciente intromisión de las potencias europeas, bajo la dirección de Muhammad bin al-Ḥayy al-Ṣiddīq al-Ghumārī (1878-1936). El sharîf procedía de la cabila de Banī ManȘūr, en Gomara, donde su abuelo, discípulo del shaykh al-Darqāwī, había fundado una zāwiya en $1807^{36}$. En 1902 intentó fundar una zāwiya en Tetuán, pero el shaykh de la Ḥarrāqiyya se lo impidió. Este es un ejemplo de la competencia entre las distintas zawāya, aunque formen parte de una misma tarīqa, puesto que la llegada a la misma ciudad de otro shaykh que podría llegar a adquirir la misma o mayor autoridad que el ya establecido se percibe como una amenaza al

35 Victor Vernier, La Singulière Zone de Tanger. Ses différents aspects et ce qu'elle pourrait devenir si... (París: Editions Eurafricaines, 1955): 59.

36 Josep Lluís Mateo Dieste, "Faccionalismo y dinámicas en el campo religioso colonial marroquí. El caso del Sharif darqāwa Bin Saddiq" en Religión y Patrimonio Cultural en Marruecos. Una aproximación antropológica e histórica, Eloy Gómez Pellón y Araceli González Vázquez (Sevilla: Signatura Demos, 2011): 217-239. 
liderazgo e influencia del más antiguo. Este hecho marcaría el inicio de una rivalidad y competencia por ejercer la mayor influencia en la zona; una situación positiva para los intereses colonialistas, puesto que podrían jugar con los apoyos a una u otra parte para conseguir sus propósitos.

El shaykh se propuso fomentar en Tánger la enseñanza religiosa tradicional, para lo que pidió ayuda al sultán Mūlāy 'Abd al-'Azīz, que le entregó una casa propiedad del Majzén en la ciudad $^{37}$. Desde su zāwiya situada en Dār al-Barūd, su fama como maestro creció y su popularidad aumentó, no solamente en Tánger sino en todo el noroeste de Marruecos. Consciente de la importancia de las alianzas para ganar poder y popularidad, se casó con la hija del líder de la zāwiya de Bin 'Ayība, Lalla Zahrā'. Esta zāwiya estaba situada en Ányera, la cabila que contaba con más seguidores en la región de Yebala. A su vez, desposó a su hermana con un familiar del mismo ${ }^{38}$, y parece que en su casa se reunían las mujeres afiliadas a la tarīqa y celebraban sus encuentros cada viernes ${ }^{39}$. Pese a tener una visión negativa del shaykh por sus intrigas y búsqueda de poder e influencia, Michaux-Bellaire reconoce

37 Ahmed Ktiouet, La Zawiya Assidiqiya de Tanger (Casablanca: Afrique Orient, 2010): 52.

38 Ktiouet, La Zawiya Assidiqiya de Tanger, 223.

39 Direction Générale des Affaires Indigénes, Villes et tribus du Maroc, VII: Tanger et sa zone (París: Ernest Leroux, 1921): 324. que Bin Șiddīq era un personaje muy respetado por su formación y su papel docente y místico ${ }^{40}$. Además de fomentar las alianzas por medio de uniones familiares, Bin Șiddīq era consciente de la importancia estratégica de la ciudad donde había fundado su zāwiya, y, como veremos más adelante, mantendría dobles juegos y relaciones ambiguas con Francia, Inglaterra y España, buscando el beneficio propio, que le permitirían aumentar su influencia en la región al mismo tiempo que gozaba de prestigio como líder religioso. Durante la I Guerra Mundial mantuvo contactos con los alemanes, y su germanofilia era de sobra conocida; durante la II Guerra Mundial la Șiddīqiyya volvería a ponerse del lado alemán. Tras su muerte en 1936, uno de sus hijos, Ahmad, ocuparía su lugar al frente de la zāwiya, y como su padre, será consciente de la importancia de las múltiples alianzas y juegos de poder que tendrá que manejar para mantener un equilibrio entre su reputación de buen musulmán y los pactos con los europeos que le garanticen poder e influencia.

\subsection{Gomara y Yebala}

Una de las cinco regiones en las que dividirían su zona de influencia las autoridades coloniales españolas en Marruecos era Gomara. Aquí, en la cabila de Banī ManṢūr, Sīdī al-Ḥayy

40 Michaux-Bellaire, "Les Derqaoua de Tanger", Revue du Monde Musulman XXXIX”, 117. 
Aḥmad bin 'Abd al-Mu'min, discípulo de al-Darqāwī, fundaría una zāwiya en 1807. Su hijo, fallecido en Tusgan en 1915, era el padre del fundador de la zāwiya de Tánger. Cuando este se marchó a Tetuán y después a Tánger para fundar una nueva zāwiya, Drague recoge que su primo Sīdī Aḥmad bin al-Hayy Șiddīq bin al-Hayy Ahmad bin 'Abd al-Mu'min se encargó de dirigir la zāwiya de Tusgan ${ }^{41}$. Unidos por lazos familiares y por intereses de expansión, ambos primos ejercerían su influencia sobre la región de Gomara. La cabila de Ban̄̄ ManȘūr está situada en el centro de la región, y a través de sus redes clientelares y peregrinaciones, Tusgan se comunicaría con Tánger. Pero esta zāwiya no era la única presencia de la tarīqa en la zona, ya que Sīdī Muhammad bin Aḥmad al-Buzaydī, otro discípulo del shaykh al-Darqāwī, había fundado una zāwiya en esa región. Al-Buzaydī murió sin descendencia, y dejó escrito que los bienes pasaran a ser administrados por la zāwiya madre de Bū Barīḥ ${ }^{42}$.

La zāwiya de Tusgan tendría que competir en influencia con la Harrāqiyya de Tetuán, que también mantenía redes clientelares, sobre todo en la zona norte. A su vez, la zāwiya madre, que extendía su influencia por todo el

41 Drague, Esquisse d'histoire religieuse an Maroc. Confréries et Zaonias, 261.

42 "Darcauas de Gomara", en Et-Tabyi, Retazos de historia marroquí (Tetuán: Editora Marroquí, 1955), 101-103.
Rif, llegaba también a Gomara a través de las cabilas del este. No obstante, Tusgan era preponderante, y gracias al prestigio y fama de Bin Siddīq, podía ejercer su influencia de una forma más eficaz. Esta competencia sería habitual en muchas de las cabilas en las que las zawāya de Tetuán y Tánger tuvieran representación e intereses.

En las cabilas de la región de Yebala también encontramos representación de ambas ciudades. La cabila de Ányera era la que más zawāya albergaba, unas veinte ${ }^{43}$, y la que más adeptos a la tarīqa contaba de toda Yebala. En esta región, los adeptos a la cofradía se dividían entre los seguidores y dependientes de la zāwiya de Tusgan, aquellos que dependían de la Harrāqiyya y, en algunas cabilas también los Darqāwa de los Bin 'Ayība, que constituían un grupo a tener en cuenta para los servicios de información españoles ${ }^{44}$. En la región del Lucus, sin embargo, la cofradía no desarrolló zawāya de importancia, pese a ser la tarīqa más extendida. La representación que allí tenía dependía de la Harrāqiyya de Tetuán, pero parece ser que no constituían un grupo numeroso, puesto que las informaciones recogidas por los servicios

43 Mateo Dieste, "Faccionalismo y dinámicas en el campo religioso colonial marroquí. El caso del Sharif darqāwa Bin Saddiq", en Religión y Patrimonio Cultural en Marruecos. Una aproximación antropológica e histórica, 221.

44 Informe sobre cofradías religiosas (1944) (Caja 2764, IDD13, AFR, AGA). 
del Protectorado en la región apenas hacen referencia a ellos ${ }^{45}$.

\subsection{La rama oriental del Kert}

En la región más oriental de la zona del Protectorado español, la zāwiya principal de los Darqāwa estaba situada en Karkar, en la cabila de Banū Bū Yahỳī. Fue fundada por Mūlāy Țayyib al- 'Uqailī, descendiente de Sīdī Muhammad Qaddūr, uno de los muchos discípulos del shaykh alDarqāwī. Parece que los descendientes de la zāwiya madre de Banī Zarwāl habrían fundado una zāwiya también en monte Karkar que competiría con los shuraffa descendientes de Qaddūr $r^{46}$. En el momento del establecimiento del Protectorado, el shaykh de la zāwiya era Sīdī Muḥammad bin Sìdī TTayyib, al que sucedería su hijo Sīdī Muḥammad bin Sīdī Sa īd bin Mūlāy Țayyib. Aunque la competencia no era tan latente como la que mantenían los centros de Tánger y Tetuán, podemos ver también en el Kert una rivalidad entre dos zawāya que se disputan el prestigio y la influencia en la región oriental. La zāwiya de Karkar se apoyaría en su condición de familia prestigiosa y largo tiempo asentada en la cabila, además de haber sido la primera

45 Intervención Territorial del Lucus, Oficina de Beni Gorfet, "Estudio económico social de esta cabila, marzo de 1954" (Caja MK-3, Expd. 6, AFR, AGA).

46 Central de Intervención de Melilla, 12 de marzo de 1928 (Caja 1225, IDD13, AFR, AGA). sede de la țarīqa en erigirse allí. Por su parte, la otra zāwiya jugaría su baza de descendiente del shaykh de Banī Zarwāl, y por tanto de la sede madre y del fundador, que también ejercía su influencia en el Kert desde el Rif.

\section{De 1912 a 1927: la cofradía y la penetración colonial española}

Desde el establecimiento del Protectorado en la zona norte de Marruecos, España tuvo que hacer frente a una serie de rebeliones que se oponían a su gobierno. Si bien estas rebeliones respondían a causas y objetivos distintos, ambas afectaron las relaciones sociales, políticas y económicas de las poblaciones y de los distintos agentes del norte de Marruecos. Las rebeliones de Aḥmad al-Raysūnī y 'Abd al-Krim afectaron también a las distintas ramificaciones de la tarīqa en el norte de Marruecos, así como a sus relaciones con el poder colonial español.

\subsection{Los Darqāwa ante Aḥmad al-Raysūnī}

Según fuentes coloniales francesas, Ahmad al-Raysūnī habría nacido en el área de Tánger alrededor de 1870, de posible ascendencia jerifiana $^{47}$. Dedicado, según estas fuentes, a la delincuencia desde su juventud, su actividad no parecía tener ningún programa o preocupación social más allá del beneficio propio. Tras pasar del

47 Direction Générale des Affaires Indigènes 1921, 108. 
servicio al sultán como caíd a ser perseguido nuevamente, con el propósito de frenar el avance de Francia en su zona de influencia, al-Raysūnī se acercó a los españoles y procuró facilitar sus operaciones, bajo la creencia de que «los españoles son fuertes para ayudarnos pero no tanto para oprimirnos ${ }^{48}$ ». Con la entrada de los españoles en Tetuán tras la firma del tratado de Protectorado, se organizó una insurrección en los alrededores encabezada por el shariff Muḥammad bin Sīdī Lạ̣san, elegido al parecer por su neutralidad ante las rivalidades intertribales ${ }^{49}$. En este momento, al-Raysūnī decidió romper las relaciones diplomáticas con los españoles y unirse a la rebelión para intentar encabezarla. Sin embargo, los partidarios de Laḥsan no confiaban en al-Raysūnī por su anterior condición de colaborador con los españoles, y pronto se estableció una rivalidad entre los partidarios de uno y de otro. La insurrección armada se extendió por la zona, y en la cabila de Banī ManȘūr, en Gomara, los servicios de información recogen la actuación del sharîf darqāwa de Tusgan, Sīdī Muhammad bin 'Abd al-Mu'min, pregonando la guerra contra el invasor extranjero y organizando grupos de combatientes por toda la región ante la ocupación de

48 James A. Chandler, "Spain and Her Moroccan Protectorate 1898-1927", Journal of Contemporary History, 10: 2 (1975): 301-322.

49 Mateo Dieste, La «hermandad» hispano-marroquí. Política y religión bajo el Protectorado español en Marruecos [1912-1956], 417.
Tetuán ${ }^{50}$. Sin embargo, años más tarde, durante la lucha de los españoles contra al-Raysūnī, los líderes de las ramas de Tánger y Tusgan, unidos por lazos familiares e intereses políticos, combatirían a al-Raysūnī del lado de los españoles. Ante la insurrección, España negoció con al-Raysūnī hasta la toma de posesión de Dámaso Berenguer como Alto Comisario en febrero de 1919. El militar emprendió una guerra de conquista en la parte occidental de la zona de influencia española, con la voluntad de partir los territorios de al-Raysūnī y buscando reducirle por la fuerza.

Durante estos años de hostilidades y acuerdos de las autoridades españolas con al-Raysūnī, la cofradía Darqāwiyya no permanecía ajena a la situación de la región, y los líderes de las ramas del noroeste ya habían tomado una postura ante los acontecimientos. La zāwiya Harrāqiyya de Tetuán era ya cliente de la administración española desde la ocupación de Tetuán, y se incluía entre los notables con los que había parlamentado España para facilitar la penetración y el avance colonial. Como tal, utilizó su influencia para combatir a al-Raysūnī en las zonas que contaban con zawāya clientes de la rama tetuaní (principalmente en Yebala). De otra parte, tenemos la zāwiya Șiddīqiyya de Tánger, liderada por Muḥammad bin Șiddīq al-Ghumārī que, en colaboración con

50 Regional de Gomara, s.a., 8. 
la zāwiya de Tusgan (con la que mantenía lazos de parentesco) extenderían su influencia por Gomara y las cabilas próximas a Tánger, abarcando prácticamente todo el territorio que llegaría a dominar al-Raysūnī.

Los Darqāwa de Gomara se habían opuesto a la política raysuniana, que minaba sus privilegios y les sometía a su autoridad despótica, lo que llevó a los líderes de la tarīqa en la zona a prestar colaboración a los españoles cuando estos, al mando de Berenguer, se decidieron a acabar con el dominio y la influencia de al-Raysūnn ${ }^{51}$. Incluso en los años de preponderancia del rebelde, su influencia en Gomara no llegó a ser efectiva gracias a la intervención de las influencias y redes clientelares de los Darqāwa ${ }^{52}$. Se habla de los hermanos Sīdī Muḥammad y Sī Aḥmad al-Baraka, influyentes darqāwa de la zona, que combatieron a al-Raysūnī en Gomara junto con el sharīf Bin Șiddīq, colaborando con el teniente coronel Castro Girona para combatirle de marzo a agosto de $1919^{53}$. En esta ocasión los Darqāwa de Tetuán se negarían a colaborar en la ocupación de la cabila de Ányera (en el norte de Yebala) por la rivalidad creciente entre el líder de esta rama y Bin Șiddīq, que

51 Regional de Gomara, s.a., 9.

52 Regional de Gomara, s.a., 9.

53 Tomás, García Figueras Marruecos, (la acción de España en el norte de África) (Madrid/Tetuán: Ediciones Fe, 1941): 169. ganaba influencia a costa de Tetuán en la zona ${ }^{54}$. Además, fruto de la colaboración con los españoles, los Darqāwa de Tánger y Tusgan nombrarían caídes afectos en las cabilas de Gomara occidental, aumentando su influencia y preponderancia en la zona, conectando la ciudad internacional con la región de Gomara a través de la zāwiya de Tusgan.

En julio de 1921, con el desastre de Annual, los militares españoles volvieron a pactar con al-Raysūnī, que recuperó su anterior poder. Pese a que algunos jefes darqāwa se mantuvieron fieles a lo pactado y continuaron en nómina española, otros, principalmente en la región de Gomara, adoptarían posiciones de desobediencia fruto de este nuevo pacto con alRaysūnī, de quien habían sufrido con anterioridad las consecuencias de su gobierno. Con el golpe de Estado del general Primo de Rivera en España en septiembre de 1923 y su postura semiabandonista respecto a Marruecos, unido al avance de las tropas rifeñas desde el este, al-Raysūnī veía doblemente amenazada su posición ${ }^{55}$. En julio de 1923 al-Raysūnī firmaba un pacto de colaboración con los españoles, una

54 Mateo Dieste, La «hermandad» hispano-marroquí. Política y religión bajo el Protectorado español en Marruecos [1912-1956], 348.

55 Abdelaziz Kh. Temsamani, País Yebala: Majzen, España y Ahmed Raisúni (Granada: Universidad de Granada y Centro de Investigaciones Etnológicas Ángel Ganivet, 1999): 139. 
declaración abierta por la que muchos de sus partidarios pasarían a combatir en el bando rifeño. En esta situación sería de esperar un doble juego de los Darqāwa de Yebala, contrarios a alRaysūnī que, sintiéndose traicionados por los españoles al haberse aliado de nuevo con él, colaborarían con los insurrectos partidarios de los rifeños. No obstante, no hay que olvidar que muchas zawāya de Yebala estaban bajo la influencia de la Ḥarrāqiyya de Tetuán, rival de las de Tánger y Tusgan, por lo que sus políticas de colaboración o ataque a las posiciones españolas estarían sujetas a las circunstancias cambiantes del momento. A medida que el poder y la popularidad de 'Abd al-Krim crecían y ganaba adeptos, alRaysūnī perdía su poder. Intentaría una última vez recuperar su poder, y con una expedición atacó y ocupó Chauen. Hizo un último llamamiento a las tribus que permanecían fieles, pero no obtuvo mucha ayuda, y en enero de 1925 Chauen fue tomada por su antiguo aliado y lugarteniente Ahmad bin Muḥammad al-Huzmarī, apodado Hmidu 1-Khriru o Jeriro. Al-Raysūnī fue hecho prisionero junto con su hijo y conducido a la cárcel de 'Abd al-Krim, donde moriría en abril de ese mismo año ${ }^{56}$.

La potencia y organización de este nuevo movimiento de resistencia

56 Mohammed Jarsis, La France et la guerre du Rif 1921-1926 (Tánger: Altopress, 2013): 130. atrajo a muchos habitantes del norte que no querían someterse al dominio español, anteriormente unidos a la rebelión raysuniana, pero desencantados por la ambición personal del sharîf. Entre ellos, multitud de afiliados a la Darqāwiyya que habían sufrido la represión de las tropas españolas por colaborar con al-Raysūnī en sus épocas de rebeldía. Sufrieron también la represión de las tropas de al-Raysūnī cuando era gobernador como parte de su política del miedo, y habrían de combatir a los rifeños en ocasiones como reclutas de aquellos que les habían reprimido anteriormente.

\section{2. 'Abd al-Krim y la țarīqa}

Muḥammad bin 'Abd al-Krim no era un sharîf ni detentaba ningún puesto de gobierno. Pertenecía a la fracción de los Aìt Yūsuf, de la cabila Aìt Wuryaghar (Beni Urriaguel), la cabila más importante de la región del Rif. El líder rifeño aprendió español y trabajó en la administración de Melilla, lo que le familiarizó con las formas de gobierno y organización del ejército $^{57}$. Tras un período de colaboración con los españoles, 'Abd al-Krim se reunió con su hermano y su padre en la montaña rifeña, donde se iniciaría la rebelión tras diversos conflictos bélicos, que acabaría liderando. Parece ser que las causas de su ruptura con los

57 Pessah, "Abd al-Qadir and 'Abd al-Krim: Religious Influences on Their Thought and Action," 162. 
españoles radicaban en la ineficacia y corrupción que 'Abd al-Krim percibía en el sistema, así como en las promesas incumplidas de progreso y desarrollo de la región, a la que solo habían llevado la guerra y la explotación para enriquecimiento de unos pocos caídes que se beneficiaban de su colaboración con las autoridades españolas.

El plan del líder rifeño para sublevar a las tribus estaba en marcha, y tras la masacre del ejército español en Annual y Monte Arruit, el avance español conseguido durante los años anteriores de ocupación progresiva había quedado reducido a los enclaves de Ceuta y Melilla en la zona oriental del Protectorado español. En la primavera de 1921 'Abd al-Krim contaba ya con una poderosa fuerza que conocía bien el terreno y basaría sus ataques en tácticas de guerrilla. Se aprovecharon de la debilidad del despliegue militar de Silvestre, que ocupaba un área cada vez mayor con el mismo número de soldados, con unas líneas de abastecimiento cada vez más delgadas y lejos de las plazas fuertes ${ }^{58}$. Su concepción de gobierno encajaba con el sistema tradicional de las tribus e introducía las novedades de un Estado moderno, con influencia de las políticas reformistas de Mustafa Kemal en Turquía. Entretanto, el avance y la conquista del territorio anteriormente ocupado

58 Temsamani, País Yebala: Majzen, España y Ahmed Raisúni, 136. por los españoles continuaban, mientras ganaba adeptos entre los antiguos partisanos de al-Raysūnī.

Su concepción de la República del Rif entraba en conflicto con el poder e influencia que tenían los jefes religiosos de la zona, entre los que destacaban los Akhamlīish (una familia de shuraf $\bar{a}^{\prime}$, no estrictamente una tarīqa), los Wazzāniyyin y los Darqāwa. Con los dos primeros grupos mantenía buenas relaciones ${ }^{59}$. Sin embargo, la relación con los Darqāwa no era la misma. Para 'Abd al-Krim, la mayoría de las turūq se oponían a su proyecto estatal, ya que pese a su capacidad intertribal, este potencial se veía frustrado por las divisiones «faccionales», puesto que cada tarīqa e incluso cada zāwiya respondía a unos intereses propios dirigidos a afianzar su poder e influencia en su $z_{\text {zona }}{ }^{60}$. Además, las prácticas de las cofradías se oponían a su pensamiento cercano a la salafiyya, aunque rehusó darle un carácter religioso a su lucha, más acorde a una concepción nacionalista: «El tiempo de las guerras santas ha pasado; ya no vivimos en la Edad Media o en la época de las Cruzadas $^{61}{ }$. Debemos recordar que la

59 Mohammed Kharchich, 2013, 136.

60 Para un estudio completo sobre las relaciones de la tarīqa Darqāwiyya con 'Abd al-Krim durante la guerra del Rif: Mustapha al-Rayis, 2016.

61 Léon Gabrielli, Abdelkrim et les événements du Rif (1924-1926) (Casablanca: Éditions Atlantide, 1953). 
Darqāwiyya no respondía a un plan de acción conjunto debido a su fragmentación y a la independencia de la zāwiya madre del resto de zawāya de la zona norte de Marruecos. Posiblemente por su gran influencia y por considerarla contraria a su proyecto unificador, el líder rifeño manifestó su oposición a la tarīqa, llegando a atacar en agosto de 1921 la zāwiya de Tusgan (ligada a la de Tánger) con una harka de rifeños (grupo de combatientes armados). Los servicios de información españoles dan cuenta de la agitación que sufrió la región de Gomara en el período posterior al inicio de la resistencia rifeña, la fuerza mayor y mejor organizada hasta la fecha. Confirman el intento de 'Abd al-Krim de ganarse a los jefes darqāwa de Gomara para su causa, y ante la imposibilidad de llevar a cabo su plan, les confisca sus bienes y les combate ${ }^{62}$.

Pese a su hostilidad, 'Abd alKrim trató de ganarlos a su causa y utilizarlos para la recluta, pero temiendo una posible represalia por parte de los españoles, los Darqāwa tomaron posiciones contrarias tras un primer acercamiento; más aún cuando el rifeño bloqueó el mercado de Tetuán y confiscó los bienes habices de las zawāya. Estos bienes alimentarían la economía de guerra y supondrían una importante aportación a su rebelión. En febrero de 1922 el Alto

62 Regional de Gomara, s.a., 11.
Comisario Berenguer pidió al sharîf Bin Șiddīq de Tánger que convenciera a las tribus de Gomara para que permitieran el avance de sus tropas, pero se creía que el líder darqāwa se relacionaba con 'Abd al-Krim en calidad de consejero, manteniendo un doble juego ${ }^{63}$, como había hecho y haría con franceses, alemanes y españoles. La represión de 'Abd alKrim no se hizo esperar, y las informaciones españolas muestran una purga de muqaddamīn en su fracción y en cabilas vecinas.

No obstante, el calificativo de rebeldes del que gozaban los Darqāwa y la desconfianza que generaba esta cofradía entre los servicios de información españoles les llevó a relacionar a 'Abd al-Krim con la tarīqa, afirmando que pertenecía a la misma. Esto podría ser cierto, puesto que no era extraño que los fieles estuvieran afiliados a más de una cofradía (aunque la Tiyāniyya sí exigía fidelidad exclusiva a la țarīqa). Además, la Darqāwiyya era la que contaba con más adeptos en su tribu y en su fracción, y 'Abd al-Krim podría haber asistido anteriormente a sus reuniones o mantener relaciones con algunos personajes influyentes (incluso para facilitar la recluta y hacer propaganda de su causa). Levi-Provençal afirma que estaba

63 Mateo Dieste, La «hermandad» hispano-marroquí. Política y religión bajo el Protectorado español en Marruecos 1912-1956, 349. 
afiliado a la zāwiya de Madaghra y por eso vestía el turbante verde, símbolo distintivo de la rama ${ }^{64}$.

Ya nos hemos referido anteriormente a la situación de la zāwiya madre de la tarīqa y a su shaykh, 'Abd al-Raḥmān al-Darqāwī, uno de los personajes más influyentes de la cabila ${ }^{65}$. Como ya hemos visto, tras el establecimiento del Protectorado, la cofradía había entablado buenas relaciones con las autoridades francesas y ya en 1915 era su principal cliente e influencia en la tribu ${ }^{66}$. Se trataba de una zona con una buena producción agrícola, necesaria para el abastecimiento del ejército que levantaría 'Abd al-Krim, así como una zona de paso fronteriza entre ambos Protectorados y entre el llano y la montaña rifeña. Aunque en un principio el sharîf se había mostrado dispuesto a colaborar con 'Abd al-Krim, similares razones que habían llevado a los Darqāwa del noroeste a no colaborar con el líder rifeño aparecieron en este caso: el temor a la confiscación de sus bienes habices para alimentar la economía de guerra; la ideología de influencia de la salafiyya y su oposición

64 Ibíd., 351.

65 Sobre el papel del shaykh al-Darqāwī como apoyo a los planes coloniales franceses: Mohammed Jarsis, "Mawqif al-zawāya min harakāt al-mujāhid Muḥammad ibn 'Abd al-Karīm al-Khațtāabī”, Nadwa al-Muqāwama al-Wataniyya bi-l-Yihād al-Husayma wa-Tāzā wa-Tāwnāt (Rabat: Manshurāt al-Mandūbiyya al-Sāmiya li-qudma al-Muqāwimīn wa-Jaysh al-Tahrî̀, 2001): 256.

66 Mustapha al-Rāyis, 2016, 22-38. a las cofradías y al culto de los santos y, en este caso, el temor a las represalias del colonialismo francés.

Una vez que fue imposible ganar su apoyo, 'Abd al-Krim comenzó a hacer propaganda contraria a los Darqāwa y limitar su influencia en la tribu, en algunas ocasiones mandando a eliminar algunos personajes influyentes. La animadversión que 'Abd al-Krim sentía por el sharīf al-Darqāwī era tal que se refería a él como 'aduw al-rahmān ("enemigo del clemente") en lugar de 'Abd al-Rahmān ("siervo del clemente) ${ }^{67}$. 'Abd al-Krim recorría las tribus limítrofes del río Wargha (la frontera natural entre ambos Protectorados en la región) buscando atraerlas a su causa y contrarrestar así la influencia del shaykh al-Darqāwī. Los franceses tomaron la iniciativa, y a finales de mayo de 1924 una columna ocupó las regiones al norte del Wargha, con el objetivo de controlar el abastecimiento de víveres del Rif y dar un pretexto a 'Abd al-Krim para actuar. El ambiente en la tribu era cada vez más tenso, y se sucedían los enfrentamientos entre los partidarios de 'Abd al-Krim, que consideraban que el shaykh había vendido su tribu a los franceses, y los de al-Darqāwī, cada vez más escasos. Al comenzar 1925 al-Raysūnī fue capturado en Tāzrūt a medida que

67 Mateo Dieste, La «hermandad» hispano-marroquí. Política y religión bajo el Protectorado español en Marruecos [1912-1956, 351. 
los españoles se retiraban de sus posiciones; la situación inquietaba cada vez más a Francia, que ya tenía otros frentes abiertos.

Con el inicio de 1925 llegaron también las hostilidades entre franceses y elementos de los Banī Zarwāl, si bien quienes dirigían los ataques eran los rifeños. El 12 de abril 'Abd al-Krim se decidió a atacar la tribu; el 15 de abril prendió fuego a la zāwiya Darqāwiyya de 'Amyūtț, y el shaykh al-Darqāwī se refugió en zona francesa, en Fez. En apenas unos días 'Abd al-Krim había ocupado toda la tribu, y para finales de mes, había tomado casi la totalidad de las tribus del Wargha. La gran ofensiva bien coordinada sobrepasó las expectativas y las delgadas líneas de defensa francesas en la zona, y en pocos días las tropas de 'Abd al-Krim se encontraban a treinta kilómetros de $\mathrm{Fez}$, amenazando la autoridad francesa y la legitimidad del sultán, títere de Francia. La ofensiva rifeña había sido abrumadora, y para detenerla, Francia recurrió a un llamamiento del sultán por todas las tribus leales para la recluta de voluntarios, que resultó ser un éxito ${ }^{68}$. Esta política, junto con el inicio de la colaboración franco-española en junio de 1925, que obligaba a Primo de Rivera a reconsiderar su posición abandonista, marcó el principio del fin del proyecto de 'Abd al-Krim.

68 David S. Woolman, Abdelkrim y la guerra del Rif (Barcelona: Oikos-Tau, 1971): 190.
La colaboración de franceses y españoles fue cercando a 'Abd al-Krim en una zona cada vez más reducida del Rif, perdiendo posiciones progresivamente. El líder rifeño se rendiría el 26 de mayo de 1926 a los franceses, pues bajo ningún concepto quería entregarse a los españoles ${ }^{69}$. Con la firma del tratado de Bāb Tāza en 1927 concluiría la llamada «pacificación» de la zona del Protectorado español de Marruecos.

\subsection{El colonialismo en práctica: la țarīqa y la DAI}

La política del Protectorado español estaba dominada, como hemos señalado con anterioridad, por el estamento militar. Este daba prioridad a la seguridad y el control y espionaje de la población, buscando desmantelar los focos de resistencia a la autoridad colonial, y dejando en segundo plano los trabajos para la mejora de infraestructuras, sanidad, educación y cultura del territorio y la población. Desde un primer momento, la Alta Comisaría y la Delegación de Asuntos Indígenas (DAI) estuvo en manos de cargos militares, explicada por el antecedente y la experiencia en la zona de las comandancias de Ceuta y Melilla y por la política de dar prioridad a acabar con la disidencia y asegurar el cese de hostilidades para poder desarrollar posteriormente las labores de gobierno.

69 Madariaga, Abd-el-Krim El Jatabi, la lucha por la independencia, 283. 
El sistema de intervención podría considerarse la espina dorsal del Protectorado español en Marruecos, y sus agentes, los interventores, constituían el elemento clave para la política de penetración española y control del territorio y la población ${ }^{70}$. Aunque existieron agentes españoles que aprendieron y se interesaron por Marruecos, lo cierto es que, hasta la creación de la Academia de Interventores en 1947, la mayoría de los españoles destinados a la intervención en las cabilas no estaban suficientemente preparados para su labor. Uno de los puntos sobre los que se insistía a los interventores en el aspecto de la penetración y del gobierno era mantener, al menos la ficción, del ejercicio de poder indirecto, dejando que fueran el caíd y los notables de la cabila quienes ejercieran el gobierno y el control directos, pero asegurando el cumplimiento de los intereses españoles.

La figura fundamental del interventor era la encargada de múltiples funciones en la cabila: en colaboración con el caíd, afín a España, debía ocuparse de numerosas tareas (administración, necesidades, mejoras, información y espionaje, ambiente de la cabila...) y de informar periódicamente a sus superiores para obtener así un conocimiento completo y detallado de toda

70 José Luis Villanova, Los interventores: la piedra angular del Protectorado español en Marruecos (Barcelona: Bellaterra, 2006). la zona. Debía aparecer ante los cabileños como el ejemplo de la «acción civilizadora» de España en Marruecos, al mismo tiempo que debía tratar de mejorar la situación de múltiples aspectos de la cabila en la que estaba destinado. Otra de sus funciones era realizar una labor de control y espionaje de posibles descontentos y levantamientos, que quedaría reflejada en informes periódicos enviados a sus superiores. La política de la Alta Comisaría de la penetración pacífica consistía en atraer a los caídes, jefes religiosos y notables de las distintas cabilas a su influencia (a base de pagos, regalos, privilegios...) para poder establecer enclaves en las distintas zonas e ir penetrando en el territorio. La colaboración con los jefes locales y regionales como medio eficaz de asegurar la labor protectora sería una constante en el discurso colonial a lo largo de todo el Protectorado:

«Una de las bases en que debe descansar la política indígena, es la compenetración con todo movimiento y evolución de las cofradías musulmanas -ya que éstas llevan anejos los del Cherifismo y el Morabitismo-, así como de sus cofrades, cuyo poder y ascendencia sobre la masa, hacen que en un momento dado, pueda ser el verdadero peligro de la paz actual del protectorado $[\ldots]^{71}$.

71 José Rodríguez Erola, "Estudio sobre los chorfa Ajamelichen", Selección de conferencias y trabajos realizados durante el curso de interventores 1951-52 (Alta Comisaría de España en Marruecos, Tetuán, 1952): 82. 
Con los líderes de las distintas ramas de la Darqāwiyya no fue distinto, y desde el establecimiento del Protectorado, las autoridades coloniales entraron en contacto con los shuyūkh, buscando atraerlos a su causa para que facilitasen la penetración en las distintas cabilas en las que contaban con zawāya bajo su autoridad. La estrategia colonial se basaba en ayudar al Majzén a establecer el control sobre «sus» territorios (valiéndose de la teoría colonial de la dicotomía makhzansỉba) y al mismo tiempo fragmentar las posiciones de los jefes de las cabilas, mediante promesas de cargos políticos, regalos y pagos periódicos ${ }^{72}$. No obstante, pese a la colaboración de sus líderes, los servicios de información españoles vigilaban muy de cerca la cofradía y las actividades de sus afiliados. Prueba de ello es la numerosa documentación producida en los años del Protectorado y recogida en el Archivo General de la Administración (AGA). Las autoridades seguían desconfiando de la organización, posiblemente fruto de la visión negativa heredada de la historiografía francesa de la que ya hemos hablado. Buena muestra son los informes de las intervenciones regionales sobre las cofradías:

« [...] La influencia de los Darkauas se tiene por considerable en toda la región Noroeste siendo o pudiendo considerarse como la última cofradía activa y vital y

72 Mateo Dieste, La «hermandad» hispano-marroquí. Política y religión bajo el Protectorado español en Marruecos [1912-1956], 140. que las enseñanzas de los Chejes Sufistas es sobre todo el medio de reunir a cuantos elementos de resistencia existen contra la penetración extranjera, aun cuando los jefes probablemente no se forjaran ilusiones sobre el éxito posible de sus esfuerzos y viven de la esperanza que hacen nacer y arraigar en los espíritus $^{73}$ ».

Pese a la estrecha vigilancia (fruto de informadores y confidentes de las cabilas y las ciudades), las autoridades españolas consideraban necesaria la atracción de la cofradía a sus intereses, y ganarse a sus líderes, al igual que a los notables de las cabilas, mediante regalos, privilegios y «donaciones» para restaurar sus edificios religiosos y mantener sus actividades.

\section{Después de la «pacificación»: la cofradía en el punto de mira}

Tras el fin de la guerra del Rif, y aunque quedaban focos de resistencia en las zonas montañosas, las intervenciones recompusieron el sistema de alianzas políticas que habían comenzado a establecer durante los primeros años. No obstante, el control recuperado sobre la zona seguía siendo precario e incompleto, y la actitud de vigilancia y desconfianza en la cofradía continuó imperando en la administración colonial. La visión negativa y generalizadora

73 Oficina Central de Intervención y Tropas Jalifianas de Melilla, Kabila de Beni Sicar, julio 1928 (Caja MK-3. Expd. 6, AFR, AGA). 
de los oficiales coloniales de los adeptos a la cofradía y sus líderes siguió marcando las pautas de actuación, tal como reflejan los manuales de formación para los interventores de la época ${ }^{74}$.

El aumento del número de discípulos de la cofradía durante los años siguientes a 1927, fue entendido por los servicios españoles como la organización de una recluta para una posterior revuelta contra la presencia colonial $^{75}$. Como medidas, además de la intensificación de la vigilancia de los cofrades más relevantes, la DAI ordenó la restricción de la ziyārāt para la recaudación, que podrían efectuarse únicamente durante la fiesta del Mawlid $^{76}$. Mientras que las autoridades españolas buscaban atraer a estos líderes, la libertad de acción y movimiento que se les permitía era limitada ${ }^{77}$. Este

74 Isaías Rodríguez Padilla, "Cofradías religiosas en el Rif y diversas Taifas de xorfas, zauias y santuarios", Curso de perfeccionamiento de Oficiales del Servicio de Intervención (Ceuta, 1930): 11.

75 En el Archivo General de la Administración (AGA) se pueden encontrar numerosos ejemplos de este control y desconfianza, como la carta de un teniente coronel de Villa Sanjurjo al Inspector General de Intervención y Tropas Jalifianas, a 3 de marzo de 1930: « [...] en la Yemaa de Tigar (Beni Uriaguel), casi todos son fokara, muy fanáticos, que se pasan la vida pidiendo a Dios que el Majzen español se marche. Todos son de la cofradía de Darkaua» (Caja 1225, IDD13, AFR, AGA).

76 Mateo Dieste, La «hermandad» hispano-marroquí. Política y religión bajo el Protectorado español en Marruecos [1912-1956], 353.

77 Carta de G. Benito a los jefes de las cinco centrales, Inspección de Intervenciones, $2^{2}$ sección, $3^{\text {a }}$ división, 3 de agosto de 1929 (Caja 1225, IDD13, AFR, AGA). temor se basaba en que los líderes de las zawāya aprovechaban estas visitas para fomentar la disidencia y tratar de organizar un levantamiento contra la presencia española, que ejercía un control débil sobre buena parte del Rif central y la zona oriental (donde había aumentado el número de adeptos a la Darqāwiyya). Tampoco les interesaba a las autoridades un aumento en los ingresos y adeptos de la cofradía, puesto que restringir las visitas y la recolección de donaciones serían buenas estrategias para evitar el crecimiento y los ingresos de la misma.

También la asistencia a la 'imāra y el volumen de adeptos que acudían a las peregrinaciones y mausoleos de la cofradía, suponían para las autoridades un medidor social de la importancia de la tarīqa. El control y la vigilancia se extendían a las tropas marroquíes, de quienes se recopilaba información sobre su afiliación a las distintas cofradías y posibles antecedentes; también se mantenía un control de algunos soldados y oficiales licenciados que tomaban parte activa en la vida de las zawāya o que destacaran por su proselitismo.

\subsection{La rebelión de Bāb Tāza}

La rebelión de Bāb Tāza es un conocido intento fallido de sublevación en el Protectorado durante el gobierno de la República. A finales de 1932, unos cabileños de Ajmas (en Chauen, Gomara), descontentos con el dominio 
español, se habrían puesto en contacto con el shariff de Tusgan, que a través de sus lazos en Tánger (el parentesco que le unía a Bin Șiddīq) habría conectado a los cabileños con los franciscanos de la ciudad internacional. Estos, contrarios a la política anticlerical del gobierno republicano, habrían tramado un complot junto con algunos elementos anarcosindicalistas para sublevar a las cabilas contra la autoridad colonial. Los franciscanos habrían transportado armas a los rebeldes, pero al no recibir el pago, la entrega no se produjo. Finalmente, el interventor de Ajmas descubrió el complot y el intento de revuelta ${ }^{78}$. Los servicios de información españoles recogen algunos testimonios que implicaban a Bin Șiddīq en el complot, pero no queda clara la participación de los franciscanos (o quizá los documentos que implicaban a la orden fueron eliminados ${ }^{79}$ ).

Al parecer, la posible implicación del sharîf darqāwa habría hecho estrechar la vigilancia en torno a él y a su círculo más estrecho. Su primo, Sīdī 'Arafa, había sido encarcelado, aunque poco tiempo después Bin Șiddīq logró su puesta en libertad y el fin de la vigilancia sobre sus padres ${ }^{80}$. La participación

78 Mateo Dieste, La «hermandad» hispano-marroquí. Política y religión bajo el Protectorado español en Marruecos [1912-1956], 161.

79 Carta del teniente coronel Puig García, Jefe de la Oficina Mixta de Información de Tánger (Caja 1268, IDD13, AFR, AGA).

80 En el AGA se conserva su ficha de detención, que recoge parentesco, filiación, fisionomía y antecedentes (Caja 64/686, AFR, AGA). en la tentativa de rebelión consolidó la imagen negativa y la desconfianza de los darqāwa como conspiradores, y el sharîf se benefició de la competencia política entre franceses y españoles por hacerse con sus servicios (información, contactos con otras zawāya) y atraerlos para sus propósitos ${ }^{81}$.

Es destacable la condición heterogénea de los participantes en la rebelión (cabileños descontentos, la Iglesia católica y la extrema izquierda española), que rompen una vez más con las posiciones y actitudes maniqueas a las que se adecua en ocasiones el discurso histórico. Sin embargo, una vez acabada la guerra civil, el régimen franquista reescribiría el incidente eliminando a los franciscanos de la ecuación:

«Con la proclamación de la funesta República y la marcha precipitada de Capaz, cambian las cosas en Gomara, y aprovechando hábilmente las circunstancias, vuelven los tuchganis a sus andadas, se restablecen las relaciones con el Cherif Ben Seddik de Tánger, los correos van y vienen constantemente, se acentúan sus trabajos en las cabilas y sus propagandas antiespañolas, aparecen pronto a germinar nuevamente ${ }^{82}$.

Las elecciones españolas de 1934 dieron el triunfo a la Confederación

81 Mateo Dieste, La «hermandad» hispano-marroquí. Política y religión bajo el Protectorado español en Marruecos [1912-1956], 354.

82 Regional de Gomara, s.a., 12. 
Española de Derechas Autónomas (CEDA), que volvió a colocar en sus puestos a oficiales próximos a la ideología derechista del nuevo gobierno. La utilización del Ejército de África y las tropas coloniales para suprimir la huelga minera asturiana de octubre de 1934 sirvió para comprobar su efectividad en la península, y este episodio convenció a los futuros golpistas de la necesidad de controlar unas tropas mejor entrenadas y preparadas que las peninsulares. El triunfo del Frente Popular en las elecciones de 1936, unido al descontento previo y a la creciente tensión entre grupos políticos radicalmente opuestos condujeron a España a una escalada de violencia política y social que culminó en el levantamiento de una parte del Ejército, fruto del complot de una serie de militares golpistas, que tenía su bastión y principal apoyo en el Protectorado y el Ejército colonial.

\subsection{Los Darqāwa y la guerra civil española}

Los militares que apoyaron el golpe de Estado eran oficiales que habían ascendido rápidamente en el escalafón por méritos de guerra durante la campaña del Rif83, afines o que formaban parte de los africanistas,

83 Agustín Blanco Izaga, Introducción a El perro de kábila y otros registros etnográficos del protectorado de España en Marruecos, de Emilio Blanco Izaga (Melilla: Servicio de Publicaciones de la UNED, 2013), 24-51. que contaban con gran apoyo en el estamento militar y las clases altas españolas asentadas en Marruecos. Tras el levantamiento y durante la guerra civil, una de las principales preocupaciones de los sublevados era el mantenimiento del orden y la recluta de contingentes marroquíes que enviarían a combatir en la península ${ }^{84}$. Para tal fin, se desarrolló una política de sobornos, engaños, castigos y represión, promesas políticas y la retórica de la «hermandad» que unía históricamente a españoles y marroquíes. En este aspecto, los líderes de las cofradías jugarían un papel determinante al oponerse o facilitar la recluta de tropas marroquíes para la guerra civil. Del mismo modo que con los notables de las cabilas, los mandos sublevados utilizarían sobornos y privilegios para conseguir que las cofradías como la Darqāwiyya no se opusieran a sus intenciones, y adoptarían una estrategia de oposición de las turūq a los líderes del nacionalismo marroquí de la zona norte. En un principio, los nacionalistas mantenían una posición contraria a la recluta, más por la negativa a que los marroquíes lucharan en una guerra que no defendía sus intereses, que por afinidad a un régimen o ideología de los contendientes. No obstante, con ellos también entablaron negociaciones los golpistas y se les

84 José Luis Villanova, El Protectorado de España en Marruecos. Organización política y territorial (Barcelona: Bellaterra, 2004): 186. 
prometieron mayores libertades y participación en la política a cambio de que no obstaculizaran la recluta ${ }^{85}$.

Tras la sublevación, los golpistas desarrollaron una intensa labor de propaganda en el Protectorado para legitimar su lucha a ojos de los marroquíes. El mensaje central se fundamentaba en que la República era un régimen contrario al Islam y las religiones, y que los marroquíes debían unirse a la lucha para combatir a los kuffär $r^{86}$, infieles o «sin Dios». En la construcción de la retórica del «Otro» durante la guerra civil, se invirtieron los papeles establecidos hasta entonces fruto del prolongado conflicto, donde el cabileño era el «salvaje» que se oponía y combatía la labor civilizadora de España. El marroquí que combatía al lado de los «patriotas» pasaba a ser el «marroquí bueno», que luchaba contra los rebeldes que querían acabar contra la «verdadera» España $^{87}$. Los militares desarrollaron una estrategia de promoción de determinados ritos, como la peregrinación a La Meca o las fiestas del mawlid y de 'id al-kabìr, la restauración de edificios

85 Abdelmajid Benjelloun, Le patriotisme marocain face au protectorat espagnol (Rabat: El Maârif $\mathrm{Al}$ Jadida, 1993): 22-30.

86 Josep Lluís Mateo Dieste, "Una hermandad en tensión. Ideología colonial, barreras e intersecciones hispano-marroquíes en el Protectorado", Awraq, 5-6 (2012): 79-96.

87 Sebastian Balfour, Abrazo mortal. De la guerra colonial a la guerra civil en España y Marruecos (1909-1939) (Barcelona: Península, 2002): 514-515. religiosos en ciudades y cabilas ${ }^{88}$, y una intensa labor de propaganda que retrataba a Franco como protector de la religión. Se enviaba a las autoridades religiosas y algunos líderes nacionalistas a las ciudades más emblemáticas de Andalucía, reforzando esa «hermandad» hispano-marroquí ${ }^{89}$.

El papel de las Intervenciones Militares sería fundamental para la recluta. Gracias a este sistema de alianzas, en el momento de la sublevación, la mayoría de los caídes y notables mantenían contactos con las Intervenciones y oficiales golpistas, que los utilizaron como método principal de recluta de tropas marroquíes. Además de los vínculos de los caídes y notables con los oficiales coloniales, que fomentaban la recluta a cambio de seguir percibiendo sus pagos y pensiones, otro de los vínculos determinantes a la hora de la sublevación y de la primera recluta era el establecido entre los oficiales españoles y las tropas coloniales, que «habían formado una comunidad de soldados en la que la fraternidad y la solidaridad eran más poderosas que la ideología o la políti$\mathrm{Ca}^{90}{ }_{\gg}$. El cerebro de la recluta fue el teniente coronel Juan Beigbeder, que contactó con los caídes de las cabilas

88 Mateo Dieste, "Una hermandad en tensión. Ideología colonial, barreras e intersecciones hispano-marroquíes en el Protectorado", 83.

89 Mateo Dieste, La «hermandad» hispano-marroquí. Política y religión bajo el Protectorado español en Marruecos [1912-1956], 163.

90 Balfour, Abrazo mortal. De la guerra colonial a la guerra civil en España y Marruecos (1909-1939), 505. 
y determinados jefes de cofradías para que justificaran la lucha como una guerra contra los infieles ${ }^{91}$. La adhesión de los notables del campo fue rápida, puesto que debían su posición a los militares, y gracias a los pagos periódicos y a la promoción de rituales religiosos y la restauración de sus edificios, los líderes de las cofradías contribuyeron a la recluta en suelo marroquí.

Se realizaron actos públicos y de propaganda que mostraban la adhesión de los notables y autoridades religiosas marroquíes al bando franquista, como la congregación de los representantes de los partidos y cofradías religiosas en diciembre de 1937 en Tetuán ${ }^{92}$. Entre estos líderes religiosos se encontraba el shaykh al-Harrāq de Tetuán, que apoyó desde el primer momento al bando sublevado y contribuyó a la recluta en las cabilas donde ejercía su influencia. Como una de las turūq más influyentes de la zona, la zāwiya de Tetuán mantenía importantes contactos con las autoridades y oficiales del Protectorado desde su instauración, y durante los años anteriores a la proclamación de la República, su shaykh y sus discípulos, muchos de ellos pertenecientes a la élite intelectual de la ciudad, se beneficiaban

91 Mateo Dieste, "Faccionalismo y dinámicas en el campo religioso colonial marroquí. El caso del Sharif darqāwa Bin Saddiq".

92 "Imponente acto de adhesión musulmana", La Gaceta de África, 7 de diciembre de 1937, Tetuán. La noticia también apareció en otros periódicos del norte de Marruecos como El Telegrama del Rif. de las buenas relaciones con los militares. Aunque estaban bajo la vigilancia de los servicios de información, como la mayoría de personajes influyentes, esto no era obstáculo para que ambas partes se beneficiaran. Tratando de anular la influencia de los líderes nacionalistas del norte, Beigbeder pensó en crear un partido político basado en las cofradías que pudiera competir con el partido de 'Abd al-Jaliq Torres, el joven líder nacionalista tetuaní. Para ello, propuso a 'Idrīs al-Ḥarrāq la creación del partido religioso Hizb al-Islāh al-Dīñ (Partido de Renovación Religiosa) $)^{93}$. Sin embargo, la medida no tuvo el éxito esperado y la propuesta no llegó a buen puerto.

Los esfuerzos republicanos por obstaculizar la recluta en el Protectorado español fueron escasos y no tuvieron éxito, debido a la preponderancia de oficiales afectos a la sublevación y a la prioridad que dio el gobierno a intentar controlar la situación en la península. Una delegación de nacionalistas marroquíes se entrevistó con el gobierno republicano para hostigar a los insurrectos y contrarrestar la recluta, a cambio de un acuerdo para conceder en la zona una amplia autonomía política y administrativa, pero no tuvo éxito. El gobierno estaba dispuesto a realizar algunas reformas y concesiones, pero no a promesas

93 Mateo Dieste, La «hermandad» hispano-marroquí. Política y religión bajo el Protectorado español en Marruecos [1912-1956], 355-356. 
de orden y política general ${ }^{94}$. A principios de 1937, Carlos Baraibar, periodista y político socialista, amigo y partidario de Largo Caballero, viajó a Tánger con el propósito de sublevar las cabilas del Rif. Se entrevistó con el presidente del Gobierno francés tras su visita a Marruecos, y pese a que parece que se iniciaron gestiones con los nacionalistas marroquíes de la zona francesa, el gobierno galo dejaría hacer pero no se comprometería a ningún tipo de ayuda, y con la condición de que este intento no fomentara movimientos independentistas en Marruecos. El proyecto fracasó cuando el gobierno republicano cayó cuando aún no se habían concluido las negociaciones ${ }^{95}$.

Tánger, por su condición de ciudad internacional y por quedar fuera de la administración directa de los sublevados, fue la ciudad donde se refugiaron muchos de los españoles y marroquíes de la zona española afectos al gobierno republicano o que huían de la represión franquista. El sharif Aḥmad Bin Șiddīq, que vivía en Egipto y estudiaba en la universidad de al-Azhar, había vuelto para sustituir a su padre en 1936 en la dirección de la zāwiya. Como nuevo líder religioso influyente, en pocos meses se vio envuelto en una compleja

94 Manuel Azaña, Obras Completas, IV (México: Ediciones Oasis, 1968).

95 Mustapha El Merroun, Las tropas marroquíes en la guerra civil española 1936-1939 (Madrid: Almena, 2003): 25. red de poderes, y entabló contactos con ambas partes del conflicto, manteniendo un doble juego de alianzas y lealtades. El nuevo shaykh también fue, como el resto de líderes religiosos, objetivo de la política de Beigbeder, que le otorgó importantes sumas de dinero y promesas de tipo político a cambio de fomentar la recluta. La DAI se enteró de sus contactos con los republicanos de Tánger, que intentaban fomentar una sublevación en la zona, y ordenó la ocupación de la zāwiya de Tusgan en septiembre de 1936, cuando Bin Șiddīq se negó a obedecer al Alto Comisario $^{96}$. Al evitar cumplir las órdenes de las autoridades franquistas, los sublevados aplicaron otros medios de presión y establecieron controles para impedir que los cofrades de la zona española accedieran a la zāwiya de Tánger, mientras la DAI creía que la influencia francesa sobre la zāwiya madre perjudicaría la recluta:

«No debemos descuidar las más nimias actividades Darkauas: el darkaui es enemigo nuestro apoyado por el francés que indudablemente es uno de sus más influyentes resortes, la zāwiya de Amjot, de gran abolengo religioso y a la que todos acatan con veneración podría originarnos serios contratiempos, que es necesario evitar ${ }^{97}$ ».

96 Mateo Dieste, "Faccionalismo y dinámicas en el campo religioso colonial marroquí. El caso del Sharif darqāwa Bin Saddiq," 230.

97 Regional de Gomara, s.a., 13. 
Las autoridades franquistas temían que Bin Șiddīq contactara con los republicanos y actuara en contra de la recluta de tropas marroquíes, e ideó el subterfugio de enviarle a Egipto en calidad de embajador del jalifa de la zona española a principios de $1938^{98}$. Esta maniobra buscaría también reducir la influencia de Bin Șiddīq y desprestigiarle para atacar a la red social que mantenía en Tánger y en las cabilas. No obstante, el sharîf no resultó demasiado mal parado, puesto que su prestigio como hombre de religión y sus importantes contactos mantuvieron su buena reputación a ojos de sus cofrades. Pese a los intentos de los sublevados por cortar sus lazos con los republicanos, en 1938 hubo otro intento de sublevar a las cabilas cuando el coronel republicano Vicente Guarner viajó a Tánger y contactó con el sharîf. Guarner cuenta los detalles de la operación en su libro" ${ }^{99}$, y cómo Bin Șiddīq, a cambio de una importante suma de dinero, ayudó en el contrabando de armas, que fueron escondidas en los sótanos del Teatro Cervantes ${ }^{100}$, y a su depósito en Cabo Espartel. Pero la operación fracasó a causa de un tiroteo con los guardias fronterizos, que tuvo como consecuencia la fuga y traición de muchos implicados marroquíes,

98 Federico Vidal, "Religious Brotherhoods in Moroccan Politics", Middle East Journal (1950): 437.

99 Vicente Guarner, Cataluña en la guerra de España, 1936-39 (Madrid: G. del Toro, 1975).

100 Resumen de un intento de revuelta (Caja 2460, IDD13, AFR, AGA). que entregaron sus armas al representante franquista de Tánger ${ }^{101}$. Un último intento de revuelta tuvo lugar en 1939, que con el apoyo de submarinos franceses y británicos, habrían desembarcado seis mil fusiles para fomentar la revuelta en la zona franquista de Marruecos. Este intento tampoco tuvo éxito, mientras los franceses seguían pagando a Bin Siddīq para que hiciera propaganda a favor de la revuelta, y los republicanos hicieron lo propio con los caídes de algunas cabilas ${ }^{102}$.

\subsection{La Darqāwiyya y el nacionalismo marroquí: «la conspiración darqāwī̄}

Desde finales de los años veinte y principios de los treinta del siglo $\mathrm{XX}$, el incipiente movimiento nacionalista marroquí del norte hizo su aparición en la escena política del Protectorado. Las primeras manifestaciones del movimiento nacionalista del norte tuvieron un carácter fundamentalmente cultural, surgidas durante los años veinte y gracias sobre todo a 'Abd al-Salām Bannūna, destacado miembro de la burguesía tetuaní ${ }^{103}$. Las manifestaciones políticas aumentarían a principios de los años treinta como reacción al Dahir Bereber del mismo año, si bien en un

101 El Merroun, Las tropas marroquies en la guerra civil española 1936-1939, 26.

102 Caja 2460, AFR, AGA.

103 María Rosa de Madariaga, Los moros que trajo Franco... La intervención de tropas marroquíes en la guerra civil (Barcelona: Martínez Roca, 2002): 207. 
primer momento no abogaban por la independencia, sino por las concesiones progresivas en materia política de educación, economía y cultura, colaborando con la administración española ${ }^{104}$. Debemos entender el término nacionalista enmarcado en un movimiento panarabista y panislámico, como respuesta al colonialismo, distinto al sentido del término europeo $^{105}$. Tras la muerte de Banūnna en enero de 1935, 'Abd al-Jaliq Torres asumió el liderazgo del movimiento nacionalista, y accedió a colaborar con la sublevación franquista, de la que esperaba mayores concesiones en materia política, fruto de las promesas que los golpistas le habían hecho para que no entorpeciera la recluta de marroquíes para la guerra ${ }^{106}$. Las autoridades franquistas eran conscientes de la creciente popularidad e influencia que tenía el movimiento nacionalista de la zona norte, hasta el momento limitado a las ciudades, y buscaría, mediante diversas estrategias, detener su extensión a las cabilas y obstaculizar una posible cooperación con otros sectores sociales marroquíes.

Además de recurrir a los notables y shurafá', los sublevados contactaron con los líderes nacionalistas del norte de Marruecos para asegurarse de que

104 Ibíd., 208-210.

105 Mateo Dieste, La «hermandad» hispano-marroquí. Política y religión bajo el Protectorado español en Marruecos [1912-1956], 283.

106 Madariaga, Los moros que trajo Franco, 231. estos no actuaban en contra de sus intereses ${ }^{107}$. Sin embargo, finalizada la guerra civil, estas promesas no se cumplirían, y los nacionalistas estarían en el punto de mira de los servicios de información españoles ${ }^{108}$, como ya lo estaban los líderes y personajes influyentes de las cofradías. Una de las medidas para contrarrestar la influencia de Torres y su partido sería la creación del ya mencionado Partido de Renovación Religiosa cuyo líder sería el shaykh de la Darqāwiyya de Tetuán, enmarcado dentro de una estrategia para evitar que el nacionalismo se extendiera a las cabilas $^{109}$, donde residía la mayor parte de la población y donde habían surgido las principales resistencias contra el dominio colonial.

Tanto en la zona gala como en el Protectorado español, las autoridades adoptaron la estrategia de oponer a las distintas zawāya con el creciente movimiento nacionalista. Los colonizadores interpretaron una vez más las divisiones religiosas entre nacionalistas y 'ulamā', por un lado, y cofradías y shurafā' por otro, como una dicotomía

107 Benjelloun, Le patriotisme marocain face au protectorat espagnol, 25.

108 Numerosos documentos sobre prohibiciones de prensa nacionalista, vigilancia de personajes influyentes del norte marroquí y sus contactos con nacionalistas egipcios (Caja M223, IDD13, AFR, AGA).

109 Abdelmajid Benjelloun, "Le mouvement nacionaliste marocain de l'ancienne zone nord et les Jbala" en Jbala-Histoire et Société. Études sur le Maroc du Nord-ouest, Ahmed Zouggari y Jawhar Vignet-Zunz (París: C.N.R.S., 1991): 91-122. 
simplista. Pasaron de considerar a las turūq como una fuerza que se oponía al colonialismo a verlas como las garantes del orden y la tradición, con el objetivo de oponerlas al incipiente nacionalismo. Aunque ambas partes seguían en el punto de mira de los servicios de información, comenzaron a utilizar a las cofradías como freno a la extensión de los wataniyyīn por las cabilas ${ }^{110}$. El shaykh darqāwa de Tánger, pagado por los españoles, atacaba en sus prédicas a los nacionalistas, mientras persistían los rumores de la creación de un partido político basado en las cofradías, que unificaría a la Kattāniyya de Fez con la Darqāwiyya de Tánger ${ }^{111}$. En otoño de 1946 el sharîf Bin Șiddīq se entrevistaba con el Alto Comisario para prestar su colaboración y obstaculizar la labor de los wațaniyy $\bar{i} n^{112}$. También los Darqāwa de Tetuán realizaban una «intensa labor de propaganda favorable a España por las cabilas ${ }^{113}$.

No obstante, esta interpretación simplista y dicotómica de las formas de creencia y participación de la religión no era real, y podemos encontrar numerosos ejemplos en los que ambas

110 Mateo Dieste, La «hermandad» hispano-marroquí. Política y religión bajo el Protectorado español en Marruecos [1912-1956], 276.

111 Información de Larache (12 de agosto de 1947) (Caja 2764, IDD13, AFR, AGA).

112 Intervención Territorial de Yebala, "Resumen territorial sobre la situación política en general", 31 de diciembre de 1946 (Caja 3007, IDD13, AFR, AGA).

113 Intervención territorial de Yebala, 1946. partes estuvieron interrelacionadas. Hasta el momento, muchos de los ' $u$ lam $\vec{a}$ ' que habían introducido las ideas reformistas en Marruecos y procedían de linajes de shuraf $\bar{a}$, , eran miembros de alguna cofradía o toleraban y aceptaban el culto a los santos. En muchas ocasiones ambos movimientos formaban un continuo, como en el caso de Tuhāmī al-Wazzān̄̄, miembro del Partido Reformista y procedente de una de las familias de shurafā ' más famosas de Marruecos, que pertenecía a la Harrāqiyya de Tetuán, pese a la posición contraria al nacionalismo de su shaykh, Sīdī 'Idrīs ${ }^{114}$. También 'Abd al-Salām Banūnna, uno de los primeros nacionalistas de la zona norte, asistía con su hijo a las reuniones de la Darqāwiyya en la cabila de Bani Hasan ${ }^{115}$, que era una zāwiya cliente de la Harrāqiyya.

Una buena muestra del contacto y la colaboración entre los líderes religiosos, en concreto de la Darqāwiyya, y los wațaniyyīn, fue el episodio que los servicios de información españoles denominaron «conspiración darqāwa», que tuvo lugar a principios de 1950 y que muestra las relaciones múltiples que existieron entre ambos grupos, más allá de la postura oficial de competencia y oposición.

114 Mateo Dieste, La «hermandad» hispano-marroquí. Política y religión bajo el Protectorado español en Marruecos [1912-1956], 286.

115 Mateo Dieste, La «hermandad» hispano-marroquí. Política y religión bajo el Protectorado español en Marruecos [1912-1956], 286. 
Desde los años treinta del siglo XX, el número de adeptos a las cofradías en general, y a la Darqāwiyya en particular, había ido disminuyendo progresivamente $^{116}$. A su vez, los cofrades estarían divididos en las zawāya de las distintas ramas de la cofradía. Los datos recogidos muestran una gran fragmentación incluso dentro de una misma cabila, siendo las más disputadas las cabilas de Yebala y Gomara, repartidos entre los leales a al-Ḥarrāq, Bin Șiddīq y Bin 'Ayība'117. La llamada «conspiración darqāwa» podría haber sido fruto de tres factores: las relaciones y contactos que existían entre nacionalistas y cofradías, más allá de la oposición a simple vista; el recrudecimiento de la política de la DAI con respecto a los wațaniyyīn, y la decadencia progresiva que sufrían las turūq. Este episodio aparece documentado como un intento de introducción de armamento de forma clandestina desde Tánger en febrero de 1950, con implicación de cofrades de la Darqāwiyya y nacionalistas marroquíes. También se hace una referencia escueta a otro intento anterior de revuelta, en el verano de 1949 y coincidiendo con los

116 "Mapa de las distintas cofradías en zona española". La Darqāwiyya contaría con 2.229 en Yebala, 183 en el Lucus, 818 en Gomara, 1.849 en el Rif y 6735 en el Kert, formando un total de 11.814 adeptos en la zona española de 1946 a 1948. Se trata de una cifra considerablemente inferior a las recogidas en años anteriores (Caja 2764, IDD13, AFR, AGA).

117 "Informe sobre cofradías religiosas" (1944) (Caja 2764, IDD13, AFR, AGA). festejos por la boda del jalifa de la zona española, con focos en Yebala, Chauen y el Lucus ${ }^{118}$.

Un informe de la Comisaría de Seguridad del 23 de febrero de 1950 recoge una conversación (por medio de un intérprete, que sería el confesor de los hechos) entre un español, aquí llamado Carlos, y el sharîf Bin Șiddīq, en la que intentarían sublevar a las cabilas de la zona española contra la autoridad franquista, apoyados por «elementos subversivos en la disidencia $^{119}{ }$. El supuesto líder de la revuelta sería un antiguo general republicano exiliado en París, que le habría dado al sharîf dinero para sobornar a los notables de las cabilas, y armas para iniciar la revuelta. Bin Șiddīq fue juzgado y encarcelado, al igual que varios de sus familiares y de su círculo cercano. Hubo varios condenados a prisión, y tres militares marroquíes implicados fueron juzgados en Consejo de Guer$\mathrm{ra}^{120}$. También aparecían como implicados en la revuelta los dirigentes del Partido Reformista Marroquí, refugiados en Tánger, 'Abd al-Jaliq Torres y Mahdī Bannūna. Durante el juicio, Bin Ṣiddīq acercó más su postura a los nacionalistas, a quienes oficialmente había atacado en sus prédicas en

118 "Complot darcaui" (Caja 2460, IDD13, AFR, AGA).

119 "Complot darcaui" (Caja 2460, IDD13, AFR, AGA).

120 "Complot darcaui" (Caja 2460, IDD13, AFR, AGA). 
tiempos anteriores, y se declaró como único culpable de la conspiración ${ }^{121}$.

Parece muy probable que, ante el auge del movimiento nacionalista, que gozaba cada vez de más apoyo, y la progresiva decadencia de la influencia de las cofradías, el habilidoso sharîf habría querido acercar posturas con los wataniyyin, para lo que se habría declarado culpable del incidente de 1950, ganándose el favor de la opinión pública marroquí. De todas formas, mediante estos ejemplos queda patente que no existió un único aspecto de oposición en las relaciones entre nacionalistas y líderes religiosos, tal como pretendían las autoridades coloniales al oponer sus posturas. Existió, como hemos visto, un contacto mayor y una colaboración contra el régimen colonial, que era precisamente lo que las autoridades trataban de evitar, puesto que constituían dos de las fuerzas sociopolíticas y religiosas más importantes de Marruecos.

\section{Conclusiones}

Los trabajos de la historiografía colonial realizados por los investigadores franceses, y más tarde por los españoles, confirman la preocupación de las administraciones del Protectorado por controlar las cofradías musulmanas. Por sus vínculos interregionales y que sobrepasaban las fronteras

121 Informe sobre el juicio a Bin Saddiq (Tetuán, 8 de abril de 1950) (Caja 2784, IDD13, AFR, AGA). coloniales, además de por su plasticidad y adaptación a la situación sociopolítica cambiante, estas instituciones eran vistas como una amenaza a la empresa colonial. Esta inquietud queda plasmada en la visión negativa que los autores coloniales tenían de las turūq, vistas como organizaciones xenófobas y contrarias a la autoridad y al «progreso y la civilización».

En relación con su aparición y desarrollo, la Darqāwiyya conoció una rápida extensión por todo el norte de África gracias a la cantidad de discípulos que congregó al-Darqāwī. Fruto de este rápido crecimiento y expansión, a la muerte del fundador, la mayoría de los centros que habían fundado sus discípulos se escindieron del original. Debido a esta fragmentación, no es posible hablar de una acción o política conjuntas de la tarīqa, como no es posible hablar tampoco de un único liderazgo. Como consecuencia, cada centro influyente siguió las políticas de sus líderes, que actuarían en consecuencia siguiendo la situación sociopolítica del momento. Una gran parte de los notables y líderes religiosos de las cabilas adoptaron una estrategia de supervivencia, y acabaron aceptando, en muchos casos con recelo, la cooperación con la administración colonial.

La pauta principal de las autoridades españolas del Protectorado en relación con las cofradías fue la 
desconfianza. Una de las características que más preocupaba al colonizador era la capacidad interregional de las turūq, que trascendían las divisiones en cabilas y regiones administrativas, y creaban vínculos sociales y lazos políticos gracias a sus redes de zawāya, sus espacios de reunión, culto y formación. En la zona del Protectorado español de Marruecos, la política de la Delegación de Asuntos Indígenas, personificada en la figura del interventor de la cabila, consistió en atraer, mediante privilegios y promesas políticas y económicas, a los notables y líderes religiosos para facilitar la penetración en el territorio que buscaban dominar. No es posible hablar de una única política de la administración española con la Darqāwiyya, del mismo modo que no existió una política uniforme de la tarīqa con las autoridades.

Pese a la colaboración de algunas de las ramas de la Darqāwiyya con las autoridades españolas, la imagen negativa del darqāwī que la historiografía colonial francesa había creado continuó siendo la imperante. Ya hemos hablado de la imposibilidad de establecer un único perfil del adepto a la cofradía, pero ese estigma permaneció en el imaginario colonial, y podemos verlo cada vez que consultamos un documento de los servicios de información o alguna obra dedicada a la formación del personal de la administración.
En cuanto a la postura de la Darqāwiyya ante los movimientos de resistencia al colonialismo español en el norte de Marruecos, hemos visto que esta no fue homogénea. En este aspecto, podríamos concluir que más que la diferencia de ideas políticas o religiosas entre los líderes de la Darqāwiyya y los de la resistencia en el norte, lo que llevó a la tarīqa a la colaboración con el colonialismo fueron las represalias de al-Raysūnī y 'Abd al-Krim, así como el temor a perder las ventajas económicas y los privilegios sociales de los que habían gozado tradicionalmente y que a su vez les reportaba la colaboración con el colonizador.

Durante la guerra civil española, la política del bando sublevado, que controlaba el Protectorado, consistió en atraer a los notables y líderes religiosos para que facilitasen la recluta de marroquíes para la guerra. Algunas zawāya como las clientes de la Harrāqiyya se declararon afines al bando franquista y colaboraron en la recluta, mientras que otras como la Șiddīqiyya o la zāwiya de Tusgan mantendrían posturas más ambivalentes y utilizarían sus redes y contactos para desarrollar un doble juego político, al tratar con franquistas, republicanos y franceses. En este sentido, podemos asegurar que el doble juego fue mantenido tanto por los líderes de la tarīqa como por los colonizadores. A unos y otros les beneficiaban estas relaciones, pero al mismo tiempo 
se desconfiaba de las verdaderas intenciones del otro; la DAI vigilaba a las cofradías mientras buscaba su colaboración, y los líderes de las turūq recibían pagos y privilegios de la administración y actuaban orientados a mantener su prestigio, ampliar el número de seguidores o asegurar su existencia.

A mediados de los años veinte $\mathrm{y}$ treinta del siglo XX, con la aparición de un nuevo actor político como el nacionalismo marroquí, las autoridades coloniales se volvieron hacia las cofradías como medio de contrarrestar la creciente influencia de los wataniyyīn. Sin embargo, los contactos y las relaciones entre los líderes y discípulos de las cofradías y los wațaniyyīn fueron más complejos de lo que la historiografía colonial refleja. Podemos poner como ejemplo el acercamiento del sharif de Tánger a los nacionalistas durante sus declaraciones en el juicio por la llamada «conspiración darqāwa».

A modo de conclusión final, podemos decir que la Darqāwiyya ha sido una pieza clave en la historia religiosa y política de Marruecos. Desde su aparición, experimentó un rápido crecimiento y expansión gracias al elevado número de discípulos de su fundador. Por otro lado, su extensión por todas las clases sociales marroquíes puso a la cofradía en el punto de mira de las autoridades precoloniales y coloniales. Por el tiempo que les tocó vivir, sus líderes se adaptaron a las circunstancias sociopolíticas del momento y la tarīqa desempeñó un importante papel en la política. La gran cantidad de personajes influyentes que pertenecieron a la tarīqa demuestra su importancia, y buena muestra de ella es la preocupación que despertó en las autoridades coloniales y que ha quedado plasmada en su producción historiográfica.

\section{Bibliografía}

Al-Wazzani, Tuhami. Az-Zāwiya. Tetuán: Maktabat an-Nasr, 1942.

Agherrabi, Najiba. Le Soufi marocain My al-Arbi al-Darqâwî. Rabat: Dar Lamane, 2010.

Al-Rayis, Mustapha. Idā,' àt hawla al-zawāya wa-İturuqiyya zamān al-himàya. Salé: "at Banī Yaznasin, Manshurat al-Zamān, 2016.

Azaña, Manuel. Obras Completas, IV. México: Ediciones Oasis, 1968.

Balfour, Sebastian. Abrazo mortal. De la guerra colonial a la guerra civil en España y Marruecos (1909-1939). Barcelona: Península, 2002.

Benjelloun, Abdelmajid. "Le mouvement nacionaliste marocain de l'ancienne zone nord et les Jbala". Jbala-Histoire et Société. Études sur le Maroc du Nord-ouest,Ahmed Zouggari y Jawhar Vignet-Zunz. París: C.N.R.S., 1991.

Benjelloun, Abdelmajid. Le patriotisme marocain face au protectorat 
espagnol. Rabat: El Maârif $\mathrm{Al}$ Jadida, 1993.

Blanco Izaga, Agustín. Introducción a El perro de kábila y otros registros etnográficos del protectorado de España en Marruecos. Emilio Blanco Izaga. Melilla: Servicio de publicaciones de la UNED, 2013.

Central de Intervención de Melilla. 12 de marzo de 1928. Caja 1225, IDD13, AFR, AGA.

Chandler, James A. "Spain and Her Moroccan Protectorate 1898. 1927". Journal of Contemporary History, 10:2 (1975): 301-322.

Chih, Rachida. "Sainteté, maîtrise spirituelle et patronage: les fondements de l'autorité dans le soufisme". Archives des sciences sociales des religions 125, (2004): 79-98.

"Complot darcaui". Caja 2460, IDD13, AFR, AGA.

"Darcauas de Gomara". Et-Tabyi, Retazos de historia marroquí. Tetuán: Editora Marroquí, 1955.

De Neveu, François Édouard. Les Khouan. Ordres religieux chez les musulmans de l'Algérie. Argel: Adolphe Jourdan, 1846.

Depont, Octave y Xavier Coppolani. Les confréries religieuses musulmanes. Argel: Adolphe Jourdan, 1897.

Direction Générale des Affaires Indigénes. Villes et tribus du Maroc,
VII: Tanger et sa zone. París: Ernest Leroux, 1921.

Drague, George. Esquisse d'histoire religieuse au Maroc. Confréries et Zaouias. París: Peyronnet, 1951.

Eickelman, Dale F. Antropología del mundo islámico. Barcelona: Bellaterra, 2003.

El Merroun, Mustapha. Las tropas marroquies en la guerra civil española 1936-1939. Madrid: Almena, 2003.

Gabrielli, Léon. Abdelkrim et les événements du Rif (1924-1926). Casablanca: Éditions Atlantide, 1953.

García Figueras, Tomás. Marruecos (la acción de España en el norte de África).Madrid/Tetuán: Ediciones Fe, 1941.

Gilson Miller, Susan. Historia del Marruecos moderno. Madrid: Akal, 2015.

Gilson Miller, Susan y Amal Rassam. "The View from the Court: Moroccan Reactions to European Penetration during the Late $\mathrm{Ni}$ neteenth Century". The International Journal of African Historical Studies, 16-1 (1983): 25-38.

Guarner, Vicente. Cataluña en la guerra de España, 1936-39. Madrid: G. del Toro, 1975.

Hammoudi, Abdallah. Maestro y discípulo. Fundamentos culturales del autoritarismo en las sociedades árabes. Barcelona: Anthropos, 2007. 
"Imponente acto de adhesión musulmana”. La Gaceta de África, 7 de diciembre de 1937. Tetuán.

Información de Larache, 12 de agosto de 1947. Caja 2764, IDD13, AFR, AGA.

Informe sobre cofradias religiosas (1944). Caja 2764, IDD13, AFR, AGA.

Informe sobre el juicio a Bin Saddiq. Tetuán, 8 de abril de 1950. Caja 2784, IDD13, AFR, AGA.

Intervención Territorial del Lucus, Oficina de Beni Gorfet. "Estudio económico social de esta cabila, marzo de 1954". Caja MK3, Expd. 6, AFR, AGA.

Intervención Territorial de Yebala. "Resumen territorial sobre la situación política en general. 31 de diciembre de 1946". Caja 3007, IDD13, AFR, AGA.

Jarsis, Mohammed. "Mawqif al-zawāya min harakāt al-mujāhid Muhammad ibn 'Abd al-Karimal-Khattābī”. Nadwa al-Muqāwama al-Wataniyya bi-l-Yihāt al-Husayma wā-Tazā wa-Tawnat. Rabat: Manshurāt al-Mandūbiyja al-Sāmiya li-qudma al-Muqāwimīn wa-Jaysh al-Tahrīr, 2001.

- La France et la guerre du Rif 1921-1926. Tánger: Altopress, 2013.

Ktiouet, Ahmed. La Zāwiya Assidiqiya de Tanger. Casablanca: Afrique Orient, 2010.
La Martinière, Maximilien A.C.H.P. y Napoleón Lacroix. Documents pour servir a l'étude du Nord Ouest Africain, Tome 1: Régions limitrophes de la frontière algérienne; les Rif, les Djebala. Argel: Service des Affaires Indigènes, 1894.

Madariaga, María Rosa de. Los moros que trajo Franco... La intervención de tropas marroquíes en la guerra civil. Barcelona: Martínez Roca, 2002.

Lacroix, Napoleón. Les Derkaoua d'hier et d'aujourd'hui. Argel: Victor Heintz, 1902.

Madariaga, María Rosa de. Abd-el-Krim El Jatabi, la lucha por la independencia. Madrid: Alianza, 2009.

"Mapa de las distintas cofradías en zona española”. Caja 2764, IDD13, AFR, AGA.

Mateo Dieste, Josep Lluís. La «hermandad» hispano-marroquí. Política y religión bajo el Protectorado espanol en Marruecos [1912-1956]. Barcelona: Bellaterra, 2003.

Mateo Dieste, Josep Lluís. "Faccionalismo y dinámicas en el campo religioso colonial marroquí. El caso del sharīf darqāwa Bin Saddiq". Religión y Patrimonio Cultural en Marruecos. Una aproximación antropológica e histórica. Eloy Gómez Pellón y Araceli González Vázquez. Sevilla: Signatura Demos, 2011: 217-239.

. "Una hermandad en tensión. Ideología colonial, barreras 
e intersecciones hispano-marroquíes en el Protectorado". Awraq, 5-6 (2012): 79-96.

- Apuntes para la historia de las cofradías musulmanas marroquies (trad. Clemente Cerdeira). Madrid: Editorial Ibero-Africana-Americana, 1923.

Michaux-Bellaire, Édouard. "Les Derqaoua de Tanger". Revue du Monde Musulman, XXXIX (1920): 98-118.

Montet, Édouard. "Les confréries religieuses de l'islam marocain: leur rôle religieux, politique et social". Revue de l'histoire des religions, 45 (1902): 1-35.

Mouliéras, Auguste. Le Maroc inconnu: étude géographique et sociologique, Deuxième Partie: Exploration des Djebala (Maroc Septentrional). París: Challamel, 1899.

Nadir, Ahmed. "Les ordres religieux et la conquête française (18301851)". Revue algeriénne des sciences juridiques, politiques et économiques, 9:4 (1972): 819-872.

Oficina Central de Intervención y Tropas Jalifianas de Melilla. Kabila de Beni Sicar, julio 1928. Caja MK-3. Expd.6, AFR, AGA.

Regional de Gomara, Delegación de Asuntos Indígenas (DAI), Servicio de Información, Publicaciones. Algunos datos sobre darkauas y aliuas, s.a.
Resumen de un intento de revuelta. Caja 2460, IDD13, AFR, AGA.

Reysoo, Fenneke. Pèlerinages au Maroc. París: Editions de la Maison des sciences del'homme, 1991.

Rinn, Louis. Marabouts et khouan. Étude sur l'islam en Algérie. Argel: Adolphe Jourdan, 1884.

Rodríguez Erola, José. "Estudio sobre los chorfa Ajamelichen". Selección de conferencias y trabajos realizados durante el curso de interventores 1951-52. Alta Comisaría de España en Marruecos, Tetuán, 1952.

Rodríguez Padilla, Isaías. "Cofradías religiosas en el Rif y diversas Taifas de xorfas, zauias y santuarios". Curso de perfeccionamiento de Oficiales del Servicio de Intervención. Ceuta, 1930.

Schaudt, Jacob. "Voyages au Maroc". Bulletin de la Société de Géographie d'Alger et de l'Afrique du Nord, VI-III (1901): 233-269.

Shinar, Pessah. "'Abd al-Qadir and 'Abd al-Krim Religious Influences on Their Thought and Action". Modern Islam in the Maghrib. Pessah Shinar. Jerusalén: Hebrew University of Jerusalem, 2004: 139-174.

Stititu, Abdallah. "Al-zāwiya wa-lmuytama al-qabili wa-l-majzan (al-zāwiya al-Darqāwiyya namudya)". Minbar Muhammad 'Abid al-Yabri, http://www.aljabriabed. net/n94_06stitou.htm (consultado el 18 de septiembre de 2016). 
Temsamani, Abdelaziz Kh. País Yebala: Majzen, España y Ahmed Raisúni. Granada: Universidad de Granada y Centro de Investigaciones Etnológicas Ángel Ganivet, 1999.

Valderrama, Fernando. "Las zāwiyas de Tetuán (estudio epigráfico)". Separata de Tamuda, I: II. Tetuán: Imprenta Cremades, 1953.

Venier, Pascal. "French Imperialism and pre-colonial rebellions in Eastern Morocco, 1903-1910". The Journal of North African Studies, 2:2 (1997): 57-67.

Vernier, Victor. La Singulière Zone de Tanger. Ses différents aspects et ce qu'elle pourrait devenir si... París: Editions Eurafricaines, 1955.
Vidal, Federico. "Religious Brotherhoods in Moroccan Politics". Middle East Journal (1950): 427-446.

Villanova José Luis. Los interventores: la piedra angular del Protectorado español en Marruecos. Barcelona: Bellaterra, 2006.

Villanova, José Luis. El Protectorado de España en Marruecos. Organización política y territorial. Barcelona: Bellaterra, 2004.

Woolman, David S. Abdelkrim y la guerra del Rif. Barcelona: Oikos-Tau, 1971. 